\title{
Proposal of two new genera of the family Zosimeidae Seifried (Copepoda: Harpacticoida): Heterozosime gen. nov. and Acritozosime gen. nov.
}

\author{
Jong Guk KIM ${ }^{\circledR 1}$ \& Jimin LEE ${ }^{\circledR 2, *}$ \\ ${ }^{1,2}$ Marine Ecosystem Research Center, Korea Institute of Ocean Science and Technology, \\ Busan 49111, Republic of Korea. \\ *Corresponding author: leejm@kiost.ac.kr \\ ${ }^{1}$ Email: jgkim@kiost.ac.kr \\ ${ }^{1}$ urn:1sid:zoobank.org:author:C26E3940-4D71-4683-8F81-4A7D0B6EC79C \\ ${ }^{2}$ urn:lsid:zoobank.org:author:B39A425E-51E7-4160-A74D-7ABFBF17A47A
}

\begin{abstract}
In the Pacific Ocean, the taxonomy of the family Zosimeidae Seifried, 2003 is poorly understood and to date only five species of the genus Zosime Boeck, 1873 are known. During oceanographic cruises exploring the species diversity of harpacticoids, two undescribed zosimeid copepods were sampled from shallow Korean waters and the deep northwestern Pacific. A detailed morphological examination has led us to propose two new genera, Heterozosime gen. nov. for the Korean zosimeid H. tenuis gen. et sp. nov. and Acritozosime gen. nov. for the deep-sea zosimeid A. spinesco gen. et sp. nov. Both new genera exhibit a distinctive feature in that the first thoracic leg has a two-segmented exopod, in contrast to the three-segmented exopod of this leg in all known zosimeid genera. Furthermore, Acritozosime gen. nov. can also be discriminated from other genera by the two-segmented endopod in second to fourth thoracic legs and the reduced setal armatures of the second exopodal segment of antenna, the first endopodal segment of first to third thoracic legs and the third exopodal segment in second to fourth thoracic legs. A comparison of the fundamental structures of appendages suggests that $A$. spinesco gen. et sp. nov. experienced a unique evolutionary history within the Zosimeidae.
\end{abstract}

Keywords. Deep sea, Korea, meiofauna, morphology, Pacific.

Kim J.G. \& Lee J. 2021. Proposal of two new genera of the family Zosimeidae Seifried (Copepoda: Harpacticoida): Heterozosime gen. nov. and Acritozosime gen. nov. European Journal of Taxonomy 760: 32-60.

https://doi.org/10.5852/ejt.2021.760.1439

\section{Introduction}

In a revision of the phylogeny of Harpacticoida Sars, 1903, Seifried (2003) removed three genera (Peresime Dinet, 1974, Pseudozosime T. Scott, 1912 and Zosime Boeck, 1873) from the family Idyanthidae Lang, 1944 and combined them into a new family, Zosimeidae Seifried, 2003. The monophyly of the family is supported by many autapomorphies, e.g., the mandibular palp exhibits a small one-segmented exopod, a stenopodial maxilliped and a unique fifth leg in both sexes (Seifried 
2003; Koller \& George 2011). Most of the 25 known species have been recorded from the Atlantic Ocean, but their geographical distribution is wide and it is estimated that the species diversity is high (Koller \& George 2011; Kim \& Lee 2019). Zosimeid copepods are found in sedimentary environments in both shallow and deep waters; only Z. mediterranea Lang, 1948 was described from an algal assemblage (Seifried 2004). In harpacticoid communities of deep-sea regions (abyssal and hadal areas), the taxon is occasionally very abundant and species-rich (e.g., Kitahashi et al. 2013; George et al. 2014; Pointner 2017; Schmidt et al. 2019).

In the Pacific Ocean, only five named species of the Zosimeidae are known: Zosime pacifica Fiers, 1991 (ranging from the littoral region to the deep sea of the Santa Maria Basin) (Fiers 1991), Z. changi Kim \& Lee, 2019, Z. comata Kim \& Lee, 2019, Z. destituta Kim, Jung \& Yoon, 2016 and Z. gymnokosmosa Kim \& Lee, 2019 (all from littoral regions of the Southern Sea, Korea) (Kim et al. 2016; Kim \& Lee 2019). However, many undescribed oceanic species of Zosime and Pseudozosime have been reported in certain ecological studies (e.g., Shimanaga et al. 2004; Kitahashi et al. 2013; Schmidt et al. 2018, 2019). As emphasized by Koller \& George (2011), the low number of known species is attributable to the lack of taxonomic studies, not species scarcity.

When taxonomically studying harpacticoid copepods from shallow waters off the Korean Peninsula and the deep Pacific Ocean, we found two new taxa closely related to the Zosimeidae. All zosimeid copepods have a first thoracic leg with a three-segmented exopod; this ramus is two-segmented in our two new taxa, thus not meeting any known zosimeid genera. We here describe these two new taxa and discuss their taxonomic positions within the family.

\section{Material and methods}

Two new zosimeid genera were found in sediment samples collected from shallow waters of the Southern Sea of Korea and in deep waters in the northwestern Pacific (Fig. 1, Table 1) during oceanographic cruises aboard the research vessels EARDO, ONNURI and ISABU. Samples were collected using a Smith-McIntyre grab, a multiple corer, and a box corer, and were freshwater-sieved through a $50-\mu \mathrm{m}$ pore-diameter net, and immediately fixed in $10 \%$ formalin. We extracted meiofaunal organisms from sediment by the centrifugal method using Ludox HS-40 ${ }^{\circledR}$ solution (Burgess 2001) in the laboratory. Zosimeid copepods were examined under a stereo microscope (Leica M165C, Germany) and temporarily mounted on slides to allow morphological examinations seeking new taxa. All line drawings were prepared using a drawing tube attached to a differential interference contrast microscope (Leica DM2500, Germany). After examination, the dissected parts of the type series were mounted (in lactophenol solution) on H-S slides (Shirayama et al. 1993) and stored in the Marine Biodiversity Institute of Korea (MABIK), Seocheon, Korea and the Marine Interstitial fauna Resources Bank (MInRB) of the Korea Institute of Ocean Science and Technology (KIOST), Busan, Korea. The morphological terminology is adopted from Huys \& Boxshall (1991). Scale bars are in micrometers.

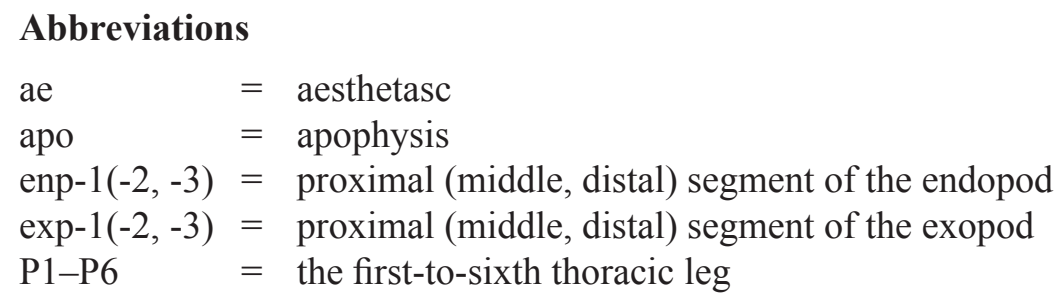




\section{Results}

Class Hexanauplia Oakely, Wolfe, Lindgren \& Zaharof, 2013

Subclass Copepoda Milne-Edwards, 1840

Order Harpacticoida Sars, 1903

Family Zosimeidae Seifried, 2003

Genus Heterozosime gen. nov.

urn:Isid:zoobank.org:act:7E707DCE-5BF1-45F8-8442-C700C3C5B83A

\section{Type species}

Heterozosime tenuis gen. et sp. nov., by monotypy.

\section{Diagnosis}

Body subcylindrical, with inconspicuous distinction between prosome and urosome; urosomites except penultimate and anal somites with pleural extensions; genital somite and first abdominal somite fused ventrally in female, forming genital double-somite. Penultimate somite with pseudoperculum comprising several projections. Rostrum undefined at base, with 1 pair of long sensilla distally, ornamented with

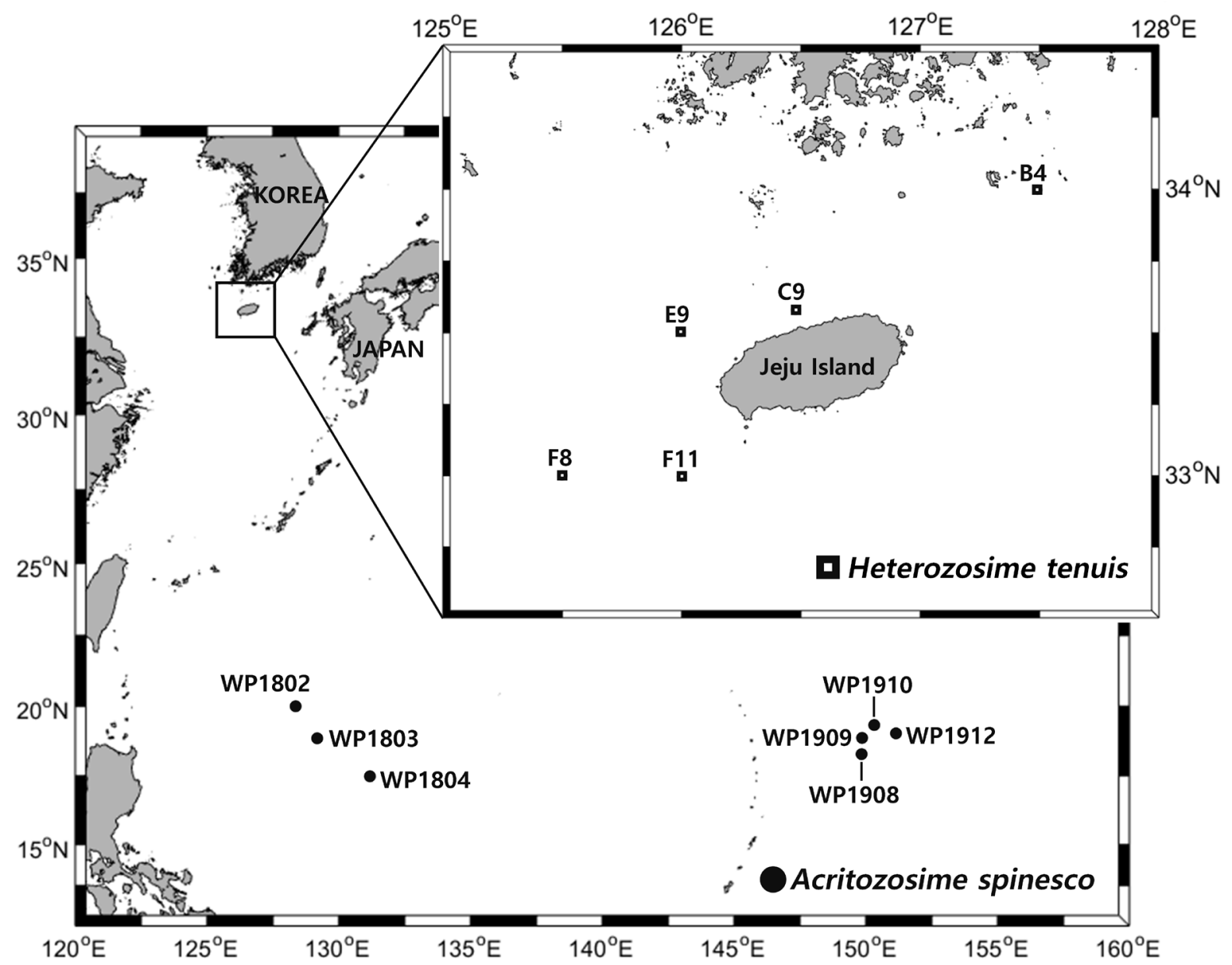

Fig. 1. Map showing the sampling stations and findings of Heterozosime tenuis gen. et sp. nov. and Acritozosime spinesco gen. et sp. nov. 
Table 1. Collection information on two zosimeid species described in the present study. ${ }^{*}$ Type locality.

\begin{tabular}{|c|c|c|c|c|c|}
\hline Species & Station & Date & Latitude & Longitude & Depth (m) \\
\hline \multirow{6}{*}{$\begin{array}{l}\text { Heterozosime tenuis } \\
\text { gen. et sp. nov. }\end{array}$} & E9 & 3 Jun. 2015 & $33^{\circ} 30^{\prime} 11.88^{\prime \prime} \mathrm{N}$ & $125^{\circ} 59^{\prime} 48.84^{\prime \prime} \mathrm{E}$ & 96.4 \\
\hline & $\mathrm{B} 4^{*}$ & 8 Jun. 2015 & $33^{\circ} 59^{\prime} 53.04^{\prime \prime} \mathrm{N}$ & $127^{\circ} 29^{\prime} 27.60^{\prime \prime} \mathrm{E}$ & 78.7 \\
\hline & F8 & 12 Nov. 2015 & $33^{\circ} 00^{\prime} 00.84^{\prime \prime} \mathrm{N}$ & $125^{\circ} 30^{\prime} 00.72^{\prime \prime} \mathrm{E}$ & 97.0 \\
\hline & B4 & 26 Apr. 2016 & $35^{\circ} 59^{\prime} 52.62^{\prime \prime} \mathrm{N}$ & $127^{\circ} 29^{\prime} 58.19^{\prime \prime} \mathrm{E}$ & 78.7 \\
\hline & F11 & 6 Aug. 2016 & $32^{\circ} 59^{\prime} 49.41^{\prime \prime} \mathrm{N}$ & $126^{\circ} 00^{\prime} 04.82^{\prime \prime} \mathrm{E}$ & 82.7 \\
\hline & $\mathrm{C} 9$ & 9 Aug. 2016 & $33^{\circ} 34^{\prime} 46.66^{\prime \prime} \mathrm{N}$ & $126^{\circ} 28^{\prime} 45.12^{\prime \prime} \mathrm{E}$ & 116.3 \\
\hline \multirow{7}{*}{$\begin{array}{l}\text { Acritozosime spinesco } \\
\text { gen. et sp. nov. }\end{array}$} & WP1802 & 19 Oct. 2018 & $19^{\circ} 59^{\prime} 37.14^{\prime \prime} \mathrm{N}$ & $128^{\circ} 21^{\prime} 49.13^{\prime \prime} \mathrm{E}$ & 5642 \\
\hline & WP1803 & 20 Oct. 2018 & $18^{\circ} 51^{\prime} 30.05^{\prime \prime} \mathrm{N}$ & $129^{\circ} 10^{\prime} 44.22^{\prime \prime} \mathrm{E}$ & 5578 \\
\hline & WP1804 & 22 Oct. 2018 & $17^{\circ} 28^{\prime} 40.73^{\prime \prime} \mathrm{N}$ & $131^{\circ} 11^{\prime} 01.68^{\prime \prime} \mathrm{E}$ & 5856 \\
\hline & WP1908* & 3 Oct. 2019 & $18^{\circ} 17^{\prime} 26.64^{\prime \prime} \mathrm{N}$ & $149^{\circ} 50^{\prime} 14.88^{\prime \prime} \mathrm{E}$ & 5317 \\
\hline & WP1909 & 4 Oct. 2019 & $18^{\circ} 51^{\prime} 56.22^{\prime \prime} \mathrm{N}$ & $149^{\circ} 51^{\prime} 40.20^{\prime \prime} \mathrm{E}$ & 5416 \\
\hline & WP1910 & 5 Oct. 2019 & $19^{\circ} 19^{\prime} 45.78^{\prime \prime} \mathrm{N}$ & $150^{\circ} 19^{\prime} 19.26^{\prime \prime} \mathrm{E}$ & 5078 \\
\hline & WP1912 & 17 Oct. 2019 & $19^{\circ} 01^{\prime} 26.40^{\prime \prime} \mathrm{N}$ & $151^{\circ} 08^{\prime} 49.56^{\prime \prime} \mathrm{E}$ & 5550 \\
\hline
\end{tabular}

lateral setules. Caudal rami elongate, longer than length of anal somite. Antennule robust, 6-segmented, with ae on second and distal segments, respectively. Antennary exopod 3-segmented; setal armature, from proximal: 1.1.4. Mandibular palp well-developed, with 3 setae on basis; exopod 1-segmented, with 3 setae; endopod 1-segmented, with 4 setae. Maxillular coxa with epipodite represented by 1 seta; exopod 1-segmented, with 3 setae; endopod 1-segmented, with 6 setae. Maxillary syncoxa with 3 endites; endopod 2-segmented. Maxilliped stenopodial, with 1 stout element on basis distally; endopod small, 1-segmented, with 4 setae. P1 with 2-segmented exopod and endopod, P2-P4 with 3-segmented exopod and endopod; exp-3 with 2 outer spines. Female P5 exopod fused to baseoendopod basally, with deep incision between exopod and endopodal lobe; exopod with 3 marginal setae and 1 surface seta. P6 represented by 3 setae.

\section{Male}

Urosome 6-segmented; pleural extensions less developed. Antennule subchirocer, 8-segmented, with ae on sixth and distal segments, respectively. P2 endopod 2-segmented; enp-2 with 1 inner plumose seta, 1 plumose distal seta and 1 small outer apophysis. P5 fused with somite basally; endopodal lobe rudimentary, with 2 small setae. Left and right P6 symmetrical, each with 2 lobes, the outer one with 1 stout spine and the inner one with 1 stout spine and 1 slender seta. 


\section{Etymology}

The generic name is a combination of the Greek 'heteros' ('different') and the name of the type genus Zosime. This reflects the close relationship with Zosime, but recognizes the significant difference in the P1 exopod segmentation.

Heterozosime tenuis gen. et sp. nov. urn:1sid:zoobank.org:act:565EFB14-0731-4CD5-AD1E-70A166D5D2FB

Figs 2-8

\section{Etymology}

The species epithet reflects the Latin adjective 'tenuis' ('thin' or 'weak'), referring to the very small seta on the distal margin of P4 enp-3.

\section{Material examined}

\section{Holotype}

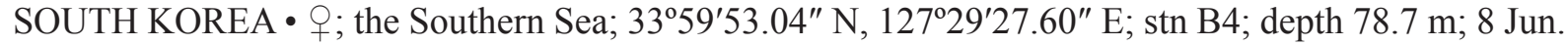
2015; O.H. Yu leg.; MABIK CR00247785 (on 11 slides, unfortunately P5 damaged during mounting process after drawing).

\section{Allotype}

SOUTH KOREA • ${ }^{7}$; same collection data as for holotype; MABIK CR00247786 (preserved in 80\% ethanol).

\section{Paratypes}

SOUTH KOREA • 1 क ; same collection data as for holotype; MABIK CR00247787 (on 11 slides) • 1 q; same collection data as for holotype; MABIK CR00247788 (preserved in $80 \%$ ethanol) 1 o ; same collection data as for holotype; MABIK CR00247789 (on seven slides, unfortunately, its mouthparts damaged).

\section{Other material}

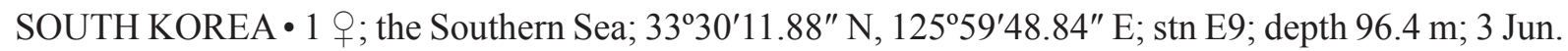
2015; O.H. Yu leg.; MInRB-Hr60-S001 (on four slides) • 1 ते; same collection data as for preceding; MInRB-Hr60-S002 (on four slides) • 2 우, 3 ऽో $\delta^{\lambda}$; same collection data as for preceding; MInRBHr60-L001 (preserved in 80\% ethanol) - 1 o ; the Southern Sea; 32 $59^{\prime} 49.41^{\prime \prime}$ N, $126^{\circ} 00^{\prime} 04.82^{\prime \prime}$ E; stn F11; depth 82.7 m; 6 Aug. 2016; O.H. Yu leg.; MInRB-Hr60-L002 (preserved in 80\% ethanol) • 1 \%; the Southern Sea; 35 59'52.62" N, 127 $29^{\prime} 58.19^{\prime \prime}$ E; stn B4; depth 78.7 m; 26 Apr. 2016; T.W. Kang

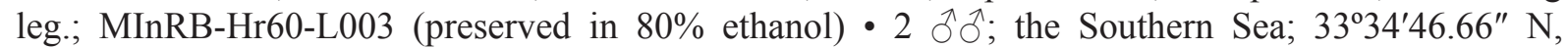
126 $28^{\prime} 45.12^{\prime \prime}$ E; stn C9; depth 116.3 m; 9 Aug. 2016; O.H. Yu leg.; MInRB-Hr60-L004 (preserved in $80 \%$ ethanol) - 8 우; the Southern Sea; $33^{\circ} 00^{\prime} 00.84^{\prime \prime}$ N, $125^{\circ} 30^{\prime} 00.72^{\prime \prime}$ E; stn F8; depth $97.0 \mathrm{~m}$; O.H. Yu leg.;12 Nov. 2015; MInRB-Hr60-L005 (preserved in 80\% ethanol).

\section{Description}

Female (based on the holotype, MABIK CR00247785)

MEASUREMENTs. Body length about 473-631 $\mu \mathrm{m}$ (mean $=569 \mu \mathrm{m}, \mathrm{n}=12$; holotype $572 \mu \mathrm{m}$ ) measured from anterior tip of rostrum to posterior end of caudal rami in lateral aspect.

Habitus (Fig. 2A-B). Subcylindrical, slightly depressed dorsoventrally, tapering posteriorly, with inconspicuous distinction between prosome and urosome. Rostrum (Fig. 2C) large, triangular, fused with cephalothorax basally; anterior tip bifid, with 2 long sensilla; anterior half ornamented with fine setules laterally. Cephalothorax large, with almost parallel lateral margins in dorsal aspect. Second 
to fourth free pedigerous somites tapering posteriorly. Urosome (Figs 2A-B, 3A) comprising P5 bearing-somite, genital double-somite, 3 free abdominal somites, more slender than prosome, tapering posteriorly; urosomites except for penultimate and anal somites with ventrolateral pleural extensions bearing sensillum distally. Genital double-somite (Figs 2A-B, 3A) separate dorsally and laterally, but completely fused ventrally; genital field located at anterior half of genital somite, with single genital slit formed by fusion of both gonopores and large mid-ventral copulatory pore posterior to genital slit; genital slit (Fig. 3A, C) covered by single large plate, on both sides with 1 stout plumose seta and 2 bare setae (inner one about 3 times as long as outer one), representing P6; each P6 distinguished by deep incision on both sides of distal margin. Penultimate somite with weak pseudoperculum comprising 4 crenate projections (Fig. 3B). Anal somite (Figs 2A-B, 3A-B) small, with semicircular operculum ornamented with small spinules and 1 pair of small peduncles bearing sensillum dorsally; anal opening wide, armed with 2 diagonal rows of setules.

BODY ORNAMENTATIONS. Integument of cephalothorax ornamented with several paired sensilla; posterior and ventrolateral margins armed with crenate processes, forming weak pseudoperculum, and small peduncles bearing sensillum. Posterior margins of somites except for penultimate and anal somites dorsally ornamented with crenate or pointed processes and small peduncles bearing sensillum; genital double-somite and second abdominal somite ventrally serrate, with 1 pair of small peduncles bearing sensillum; penultimate somite with 3 crenate protrusions laterally and row of spinules ventrally; anal somite ventrally with row of spinules at base of caudal rami. Epimera of free pedigerous somites with 1 (in P3-P4) or 2 (in P2) crenate processes, 2 small peduncles bearing sensillum and 1 row of anterior minute spinules. Pleural extensions on urosomites armed with spinules. Dorsal surface of genital doublesomite, second and third abdominal somites ornamented with minute spinules posteriorly. Anal somite with 1 pair of dorsolateral pores and 3 pairs of ventrolateral pores.

CAudal RAmi (Figs 2A-B, 3A-B). About 2.8 times as long as greatest width, about 1.5 times as long as anal somite, with 1 pore on ventrolateral surface; with 7 setae: ventrolateral seta I bare, short, slightly shorter than half length of ramus, inserted in mid-length of outer margin; dorsolateral seta II bare, shorter than seta I; seta III ventrally arising from outer distal corner, slightly shorter than caudal ramus, with weakly pinnate outer margin; principal setae IV and V well-developed, covered with minute spinules distally, with internal fracture plane proximally; seta IV about 2.7 times as long as ramus; seta V about twice as long as seta IV; seta VI located at inner distal corner, slightly longer than seta I; seta VII triarticulate basally, arising from small peduncle located on dorsal surface subdistally.

Antennule (Fig. 4A). Robust, short, 6-segmented. First segment ornamented with 2 rows of spinules along inner margin, with 1 long pinnate seta subdistally. Second segment largest, subdivided by incomplete suture, with 1 bare seta, 7 plumose setae ( 1 bi-articulate basally and 6 non-articulate), 6 spinulose setae, 5 stout tri-spinulose setae and 1 ae, which is basally fused to adjacent tri-spinulose seta. Third segment small, with 1 weakly pinnate seta and 1 stout tri-spinulose seta. Fourth segment with 1 small spinulose seta, 2 plumose setae and 3 tri-spinulose setae; outer margin produced, with 1 bare bi-articulate seta distally. Fifth segment smallest, with 1 weakly pinnate seta. Distal segment small, with 1 stout tri-spinulose, 2 weakly pinnate and 4 bi-articulated bare setae and 1 ae, which is basally fused to adjacent tri-spinulose seta. Setal armature formula as: 1-[1], 2-[18+(1+ ae)], 3-[2], 4-[7], 5-[1], 6-[6+ $(1+\mathrm{ae})]$.

Antenna (Fig. 4B). Coxa small, unornamented. Basis elongate, ornamented with 1 row of spinules on lateral surface and 2 short rows of spinules along abexopodal margin, with 1 spinulose abexopodal seta. Exopod 3-segmented; proximal segment elongate, with 1 plumose seta; middle segment smallest, with 1 spinulose seta; distal segment longer than first and middle segments combined, with 1 spinulose seta on lateral margin proximally and 1 serrate and 2 spinulose setae on distal margin. Endopod 2-segmented; 


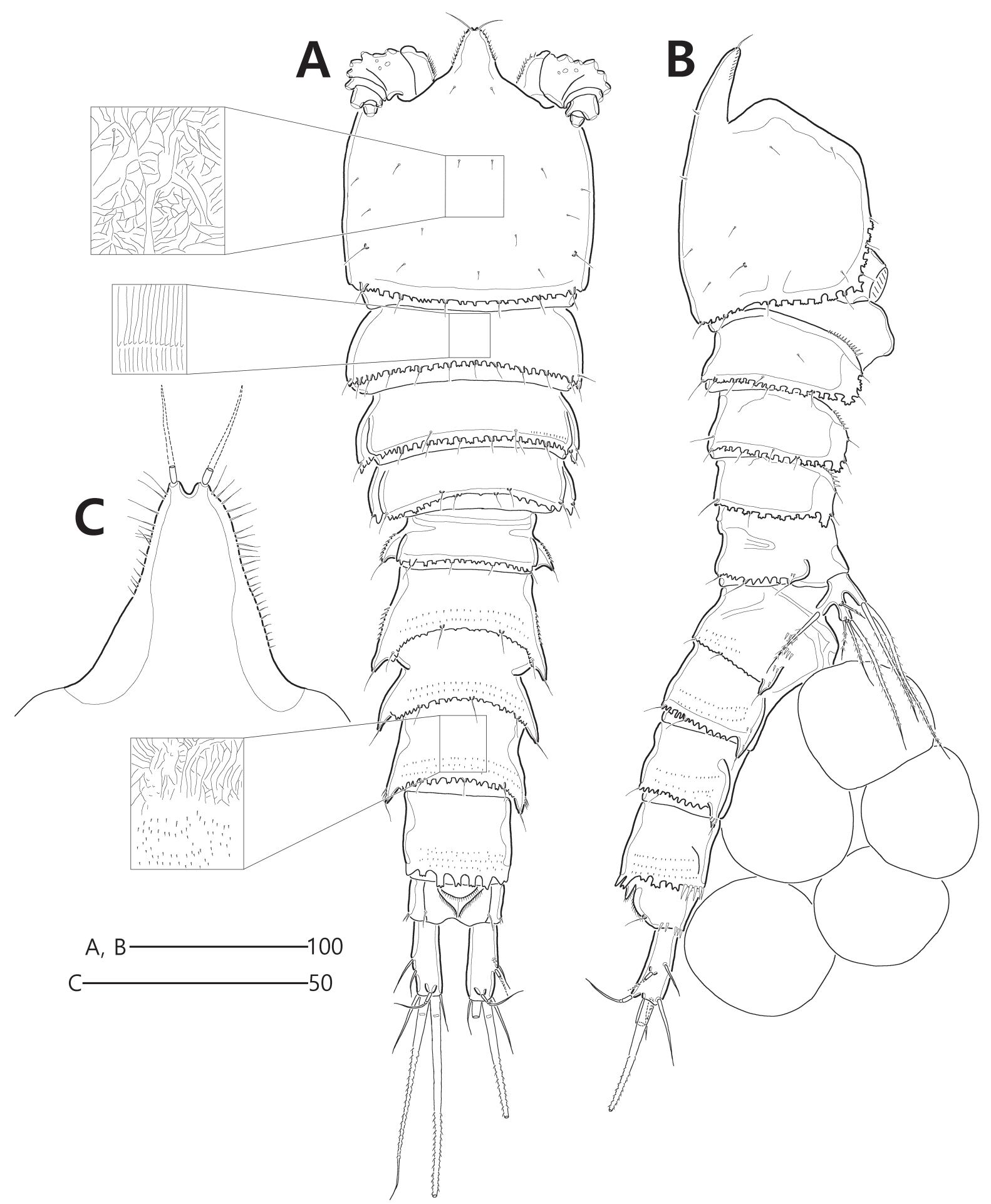

Fig. 2. Heterozosime tenuis gen. et sp. nov. Holotype, $q$ (MABIK CR00247785). A. Habitus, dorsal view, inserts show details of surface at high magnification $(\times 1000)$. B. Habitus, lateral view. C. Rostrum, dorsal view. 

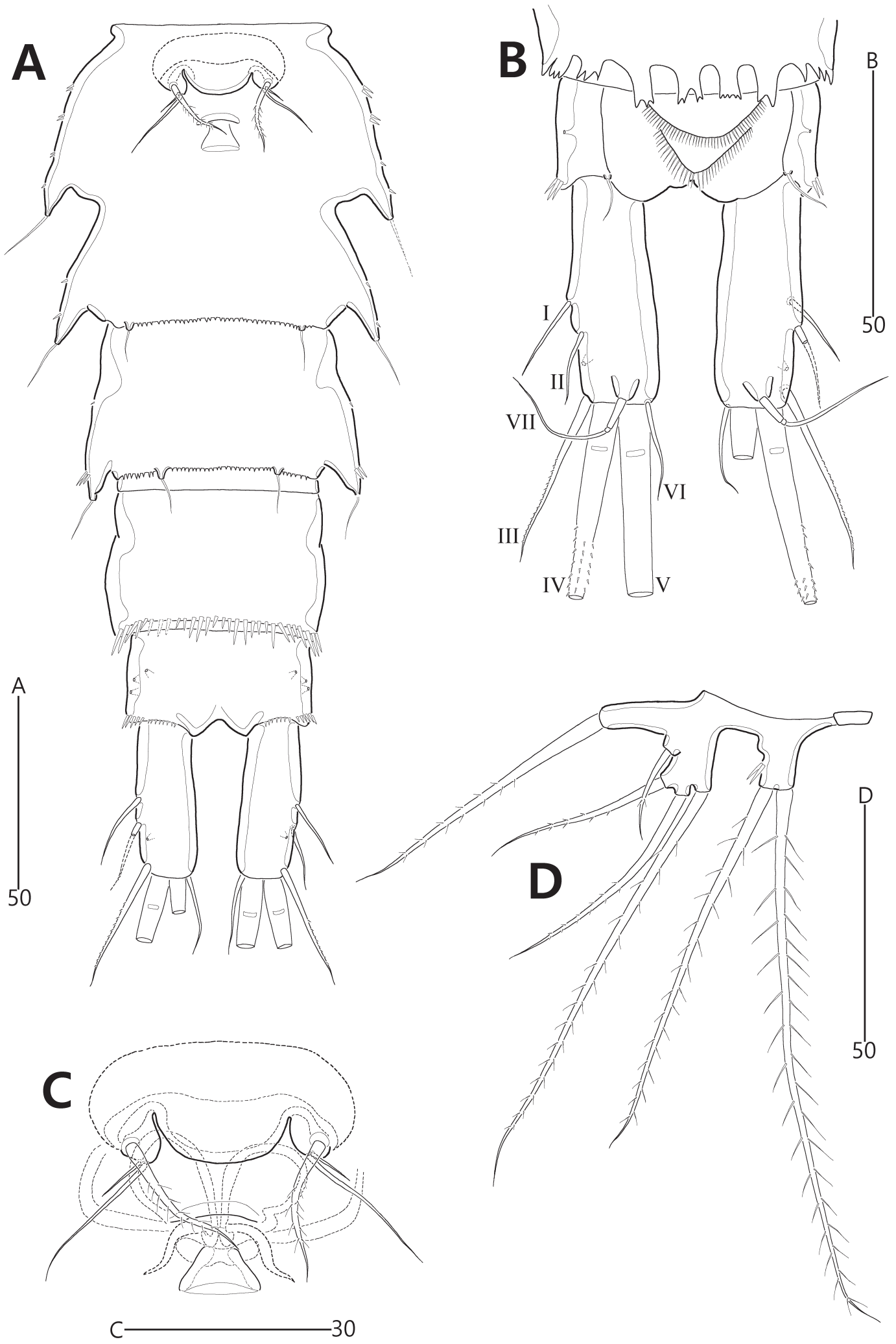

Fig. 3. Heterozosime tenuis gen. et sp. nov. Holotype,, (MABIK CR00247785). A. Urosome excluding P5-bearing somite, ventral view. B. Posterior end of penultimate somite, anal somite, and caudal rami, dorsal view. C. Genital field, ventral view. D. P5. 


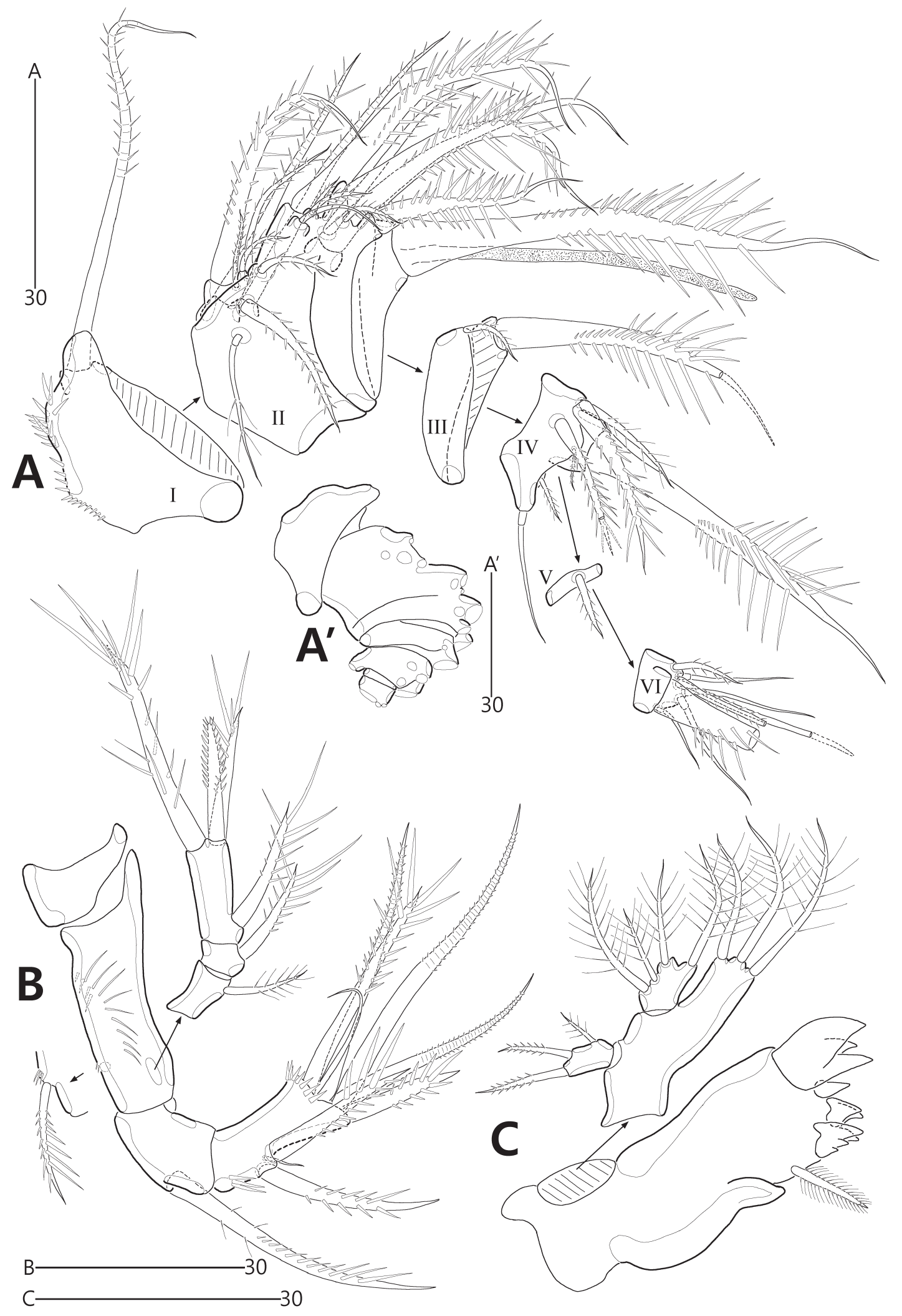

Fig. 4. Heterozosime tenuis gen. et sp. nov. Holotype, $q$ (MABIK CR00247785). A. Antennule. $\mathbf{A}^{\prime}$. Antennule without ornamentation. B. Antenna. C. Mandible. 
proximal segment with 1 long spinulose seta on abexopodal margin; distal segment about 1.8 times as long as preceding segment, ornamented with 1 group of lateral spinules and 1 row of subdistal spinules; lateral armature comprising 1 small bare and 2 stout spinulose setae; distal armature comprising 1 stout spinulose spine, 1 stout spinulose seta, 3 pinnate geniculate setae and 1 slender seta, which is fused basally with adjacent spinulose seta.

MANDible (Fig. 4C). Coxa with bulge medially; gnathobase armed with 1 small and 3 multicuspidate teeth and 1 pinnate dorsal seta. Palp composed of basis, endopod and exopod; basis elongate, with 3 plumose setae distally; exopod 1-segmented, slightly smaller than endopod, with 1 plumose and 2 pinnate setae; endopod 1-segmented, with 4 plumose setae.

MaXillule (Fig. 5A). Praecoxal arthrite well-developed, with 2 juxtaposed setae on anterior surface; distal margin armed with 8 stout spines and 1 delicate seta. Coxa ornamented with 1 row of spinules on anterior surface distally; epipodite represented by 1 plumose seta; endite with 3 bare setae distally and 1 bare seta subdistally. Basis armed with 1 row of spinules on dorsal margin and 1 row of spinules on anterior surface subdistally; with 2 endites: dorsal endite with 1 plumose and 2 bare setae distally and 2 bare setae subdistally; ventral endite weak, with 2 bare setae distally. Exopod 1-segmented, with 3 plumose setae. Endopod 1-segmented, larger than exopod, with 3 plumose and 3 bare setae.

MaXiLla (Fig. 5B). Syncoxa large, ornamented with 2 short rows of spinules along outer margin; two praecoxal endites fused basally, proximal one with 3 setae ( 1 plumose, 1 bare and 1 spinulose) and distal one with 3 setae ( 1 bare and 2 spinulose); proximal coxal endite elongate, with 3 setae ( 1 bare, 1 pinnate and 1 spinulose); distal coxal endite with 1 stout serrate spine and 2 setae ( 1 slender bare and 1 stout spinulose). Allobasis with 1 seta near base of endopod; endite with 2 stout serrate spines distally and 2 bare setae subdistally. Endopod small, 2-segmented; proximal segment with 3 bare setae laterally; distal segment with 3 bare setae distally.

MAXILLIPED (Fig. 5C). Maxilliped 3-segmented, comprising syncoxa, basis and 1-segmented endopod. Syncoxa trapezoidal, ornamented with 1 row of long inner spinules proximally. Basis elongate, as long as preceding segment, ornamented with 1 row of inner spinules subdistally, with 1 stout spinulose seta distally. Endopod small, rectangular, with 2 plumose setae on distal margin, of which inner one about twice as long as outer one and 2 bare setae on lateral margin.

P1 (Fig. 5D). Praecoxa lacking in the figure. Intercoxal sclerite wide, unornamented. Coxa large, ornamented with 3 rows of spinules on anterior surface, 1 row of minute spinules on distal margin and 1 row of posterior spinules near outer distal corner. Basis ornamented with 2 groups of spinules on anterior surface, 1 row of spinules on distal margin of pedestal of inner ramus and 1 row of long setules along inner margin; outer setophore small, with a few anterior spinules and 1 spinulose spine; inner spine spinulose, reaching to mid-length of enp-2, arising from small peduncle bearing few anterior spinules. Both rami 2-segmented; exopod reaching to mid-length of enp-2; exp-1 ornamented with outer spinules and inner setules, with 1 spinulose outer spine; exp-2 ornamented with outer spinules, with 3 spinulose spines along outer margin, 1 small spinulose spine and 1 long spinulose seta on distal margin and 2 plumose setae on inner margin; all outer spines on exopod with gradually enlarged outer spines toward distal tip; enp-1 slightly longer than wide, ornamented with 1 row of setules on outer margin and 1 row of spinules near outer distal corner, with 1 plumose seta on inner margin; enp-2 elongate, about 1.2 times as long as enp-1, ornamented with outer spinules along outer margin, with 1 small spinulose outer spine, 1 long spinulose distal spine and 2 plumose inner setae (Table 2).

P2-P4 (Figs 6A-B, 7A). Praecoxae short but wide, ornamented with 1 row of minute spinules on distal margin (praecoxa of P3 lost during dissection). Intercoxal sclerite pentagonal, with concave rear edge. Coxae large, ornamented with 3 rows of spinules on anterior margin, 1 row of spinules at outer distal 

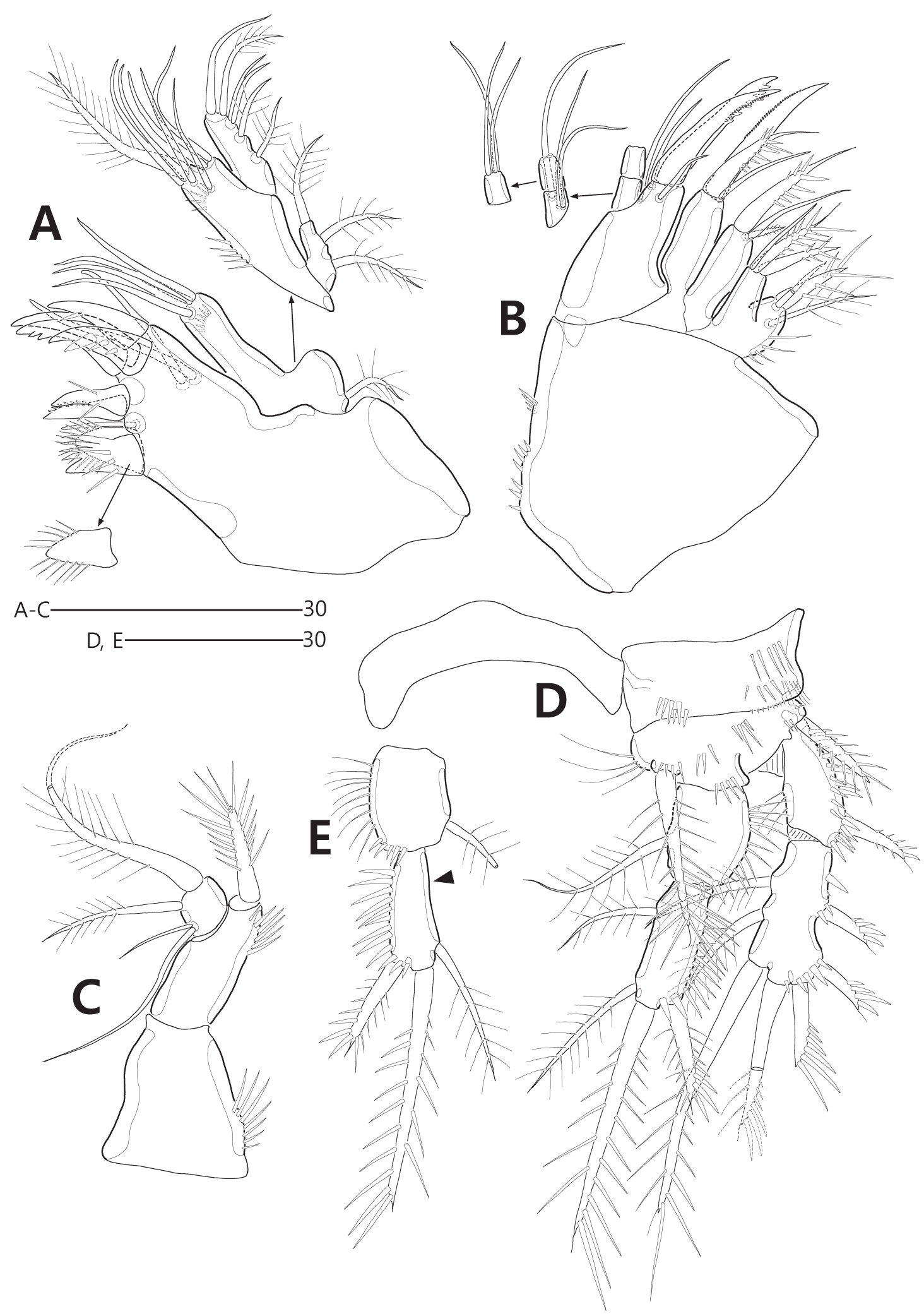

Fig. 5. Heterozosime tenuis gen. et sp. nov. Holotype, ${ }^{\circ}$ (MABIK CR00247785). A. Maxillule. B. Maxilla. C. Maxilliped. D. P1. E. Abnormal condition of P1 endopod; arrowhead indicates the absence of the proximal seta on enp-2. 
corner and 1 row of posterior setules (absent in P4) near lateral margin. Bases ornamented with 1 row of distal spinules on pedestal of inner ramus and 1 row of long setules on inner margin; anterior surface with 2 groups of spinules in P2; outer seta stout, plumose, arising from outer setophore bearing 1 row of anterior spinules; length of outer setae gradually increasing from P2 to P4. Both rami 3-segmented; exopod longer than endopod; endopod reaching to mid-length of exp-3 in P2, slightly exceeding end of exp-2 in P3, and reaching to distal fourth of exp-2 in P4; each exopodal segment ornamented with outer and distal spinules and inner setules; exp-1 elongate and exp-2 shortest, each with 1 pinnate outer spine and 1 plumose inner seta; exp-3 with 2 pinnate outer spines, 1 pinnate outer distal spine (with plumose inner margin), 1 plumose inner distal seta and 2 plumose inner setae; enp-1 and enp- 2 ornamented with outer setules, distal spinules and a few inner spinules, with 1 plumose inner seta, respectively; enp-3 ornamented with outer spinules, minute distal spinules, a few fine inner setules and 1 or 2 posterior spinules; P2-P3 enp-3 with 1 pinnate outer spine, 2 plumose distal setae and 1 inner plumose seta; P4 enp-3 with 1 long pinnate outer spine, 1 delicate outer distal seta, 1 plumose inner distal seta and 1 plumose inner seta; length of outer spines on enp-2 gradually increasing from P2 to P4 (Table 2).

P5 (Fig. 3D). Left and right legs connected by small intercoxal sclerite. Baseoendopod short, wide; outer setophore well-developed, bearing 1 long pinnate seta; endopodal lobe elongate, reaching to distal third of exopod, with 2 long plumose distal setae, of which inner one about 1.4 times as long as outer one; ornamented with a few spinules on outer margin. Exopod basally fused to baseoendopod, with 3 marginal setae, of which inner most one about 1.8 times as long as two other elements and 1 small seta arising from small peduncle on anterior surface near outer margin.

Male (based on the paratype MABIK CR00247789)

Measurements. Body (Fig. 8A) length smaller than in female, 406-474 $\mu \mathrm{m}$ (mean $446 \mu \mathrm{m}, \mathrm{n}=9$; allotype $406 \mu \mathrm{m}$ ). Sexual dimorphisms shown in urosome, antennule, P2 endopod, P5 and P6.

Urosome (Figs 7B, 8A). Urosome 6-segmented; genital somite and first abdominal somite separated; pleural extensions less developed than those of female; ventral surfaces of first and second abdominal somites (Fig. 7B) with 1 row of medial spinules posteriorly.

AnTEnNUle (Fig. 8B). Subchirocer, 8-segmented. First segment ornamented with 3 groups of spinules along inner margin, with 1 long pinnate seta. Second segment with 1 long pinnate seta. Third segment with 1 bare bi-articulate, 1 tri-spinulose and 6 pinnate setae. Fourth segment with 1 bare bi-articulate, 1 stout tri-spinulose, 1 bare, 2 small pinnate and 3 long spinulose setae. Fifth segment smallest, with 1 bare seta and 1 pinnate seta. Sixth segment stout, with 1 bare seta, 3 plumose setae, 4 small pinnate setae, 3 tri-spinulose setae and 1 ae, which is basally fused to adjacent long tri-spinulose seta. Seventh segment with 1 bare bi-articulate seta. Distal segment with 1 stout tri-spinulose, 3 plumose and 6 triarticulate setae and 1 ae, being basally fused to adjacent plumose seta. Setal armature formula as: 1-[1], 2-[1], 3-[8], 4-[8], 5-[2], 6-[10+(1+ae)], 7-[1], 8-[9+(1+ae)].

P2 ENDOPOD (Fig. 6C). P2 endopod 2-segmented by fusion of original enp-2 and enp-3; enp-1 as in female except for presence of anterior pore subdistally; distal segment elongate ornamented with long outer spinules proximally, small outer spinules distally, a few spinules on anterior surface and 1 anterior tube pore subdistally; with 1 plumose inner seta proximally, 1 plumose distal seta and 1 stout outer apophysis.

P5 (Fig. 7B). Basally fused with somite. Left and right baseoendopod confluent medially; with welldeveloped outer setophore bearing 1 long weakly pinnate seta; endopodal lobe rudimentary, represented by 2 bare setae. Exopod small, basally fused with baseoendopod, with 1 weakly pinnate and 2 bare setae on distal and subdistal margins and 1 small seta arising from anterior surface of baseoendopod between outer setophore and exopod. 
Table 2. Setal formula of thoracic legs of two zosimeid species described in the present study. The notation of the setal formula follows Huys et al. (1996).

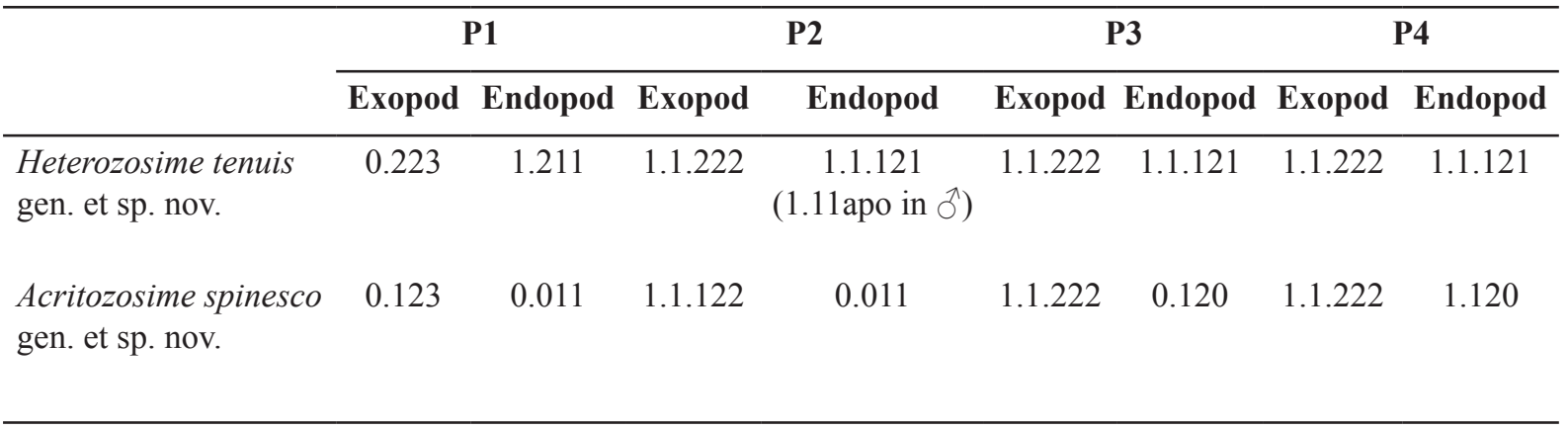

P6 (Fig. 7B). Symmetrical, represented by well-developed plate; each plate with 2 lobes distally; outer one with 1 weakly pinnate spine; inner one ornamented with few anterior spinules, with 1 weakly pinnate outer spine and 1 small bare inner seta.

\section{Variability}

Holotype female specimen (MABIK CR00247785) displays an abnormal condition in the P1 enp-2 of the right ramus, lacking a proximal inner seta (Fig. 5E; arrowhead).

\section{Remarks}

There is no doubt in allocating Heterozosime tenuis gen. et sp. nov. to the Zosimeidae on account of morphological features of the antenna, mouthpart appendages, P1 and P5 in both sexes, which are identical with autapomorphies given by Seifried (2003). Significantly, this new species is morphologically similar to the typica-group of Zosime, as defined by Kim et al. (2016), on the basis of certain features such as the mandibular endopod with four setae; the maxillulary free endopod with six elements; the outer spines of the P1 exopod with gradually increasing outer spinules toward the distal end; the typical female P5 with a deep incision between the exopod and endopodal lobe and a well-developed cylindrical outer setophore; and the outermost seta of the P5 exopod displaced by a small peduncle toward the surface in both sexes. However, it is identified by a two-segmented exopod in the P1. All known zosimeid copepods exhibit constant $\mathrm{P} 1$ segmentation with a three-segmented exopod.

The two-segmented exopod in P1 is not common within the Harpacticoida (Moura \& Martínez Arbizu 2003); we could not assign this Korean species to any well-defined genus in the family. We thus postulate that the two-segmented exopod of P1 is a significant autapomorphy of $H$. tenuis gen. et sp. nov. within the family and that our proposal of a new genus, Heterozosime gen. nov., for H. tenuis gen. et sp. nov. is reasonable. In the Idyanthidimorpha, proposed by Seifried (2003), which comprises only the two families Idyanthidae and Zosimeidae, this striking feature is evident in three idyanthid genera - Styracothorax Huys, 1993, Aspinothorax Moura \& Martínez Arbizu, 2003 and Meteorina George, 2004 - but also in the new zosimeid genus Acritozosime gen. nov. proposed in the present study (Huys 1993; Moura \& Martínez Arbizu 2003; George 2004).

Notably, this new species shares the presence of two outer spines on the P2-P4 exp-3 with four Zosime species: Z. bathyalis Por, 1967, Z. changi, Z. comata and Z. gymnokosmosa. The latter three species were reported from the Southern Sea of Korea, which includes the type locality of H. tenuis gen. et sp. nov. Nevertheless, $H$. tenuis gen. et sp. nov. displays an additional noteworthy characteristic: fine setules on the lateral margins of the rostrum in both sexes. 
The shape of the H. tenuis gen. et sp. nov. male $\mathrm{P} 2$ is very similar to that of $Z$. changi, which also has a two-segmented endopod. As suggested by the position of the setal armature in the P2 endopod, this is the result of the fusion of the original middle and distal segments in both species.

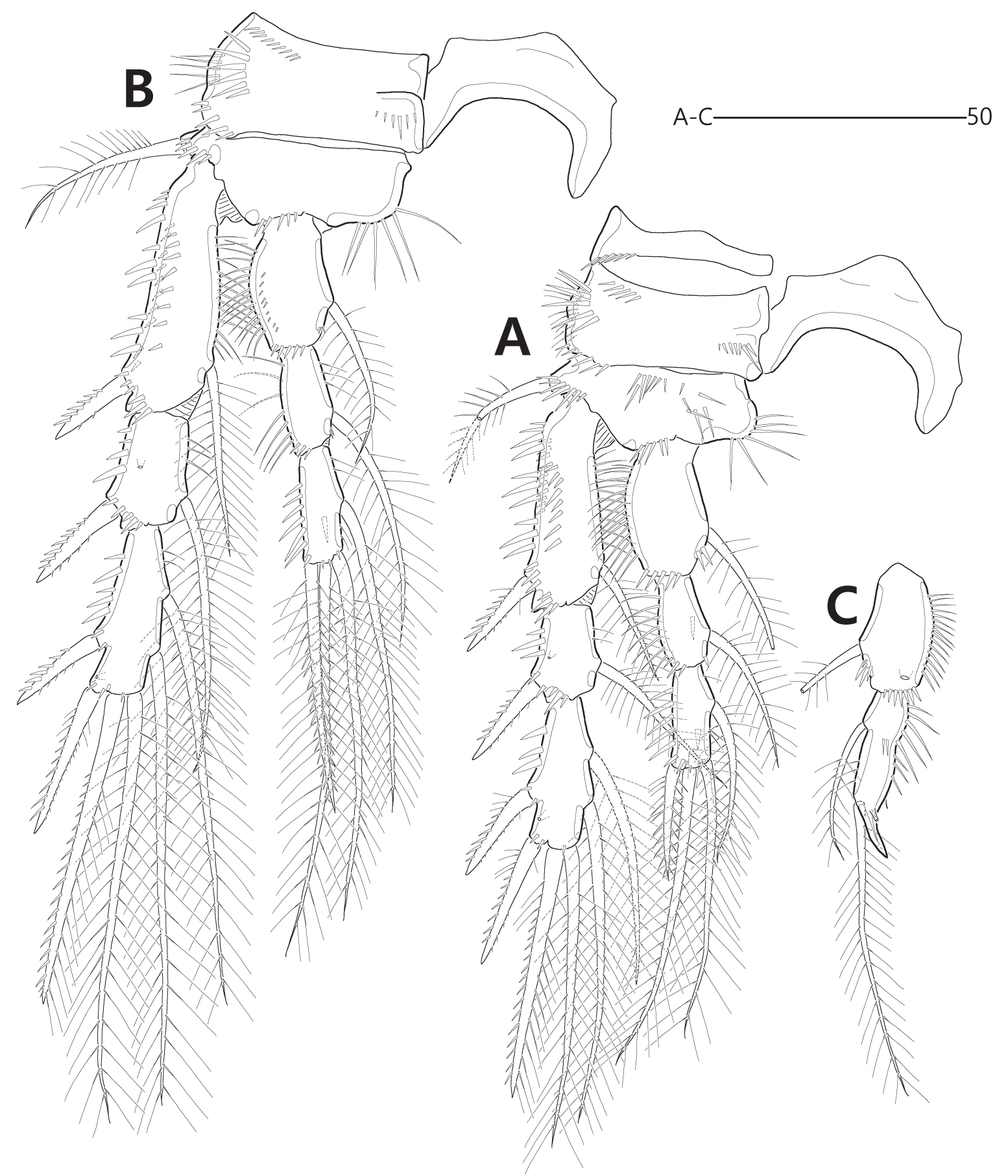

Fig. 6. Heterozosime tenuis gen. et sp. nov. A-B. Holotype, q (MABIK CR00247785). A. P2. B. P3. C. Paratype, $\widehat{o}$ (MABIK CR00247789). P2 endopod. 


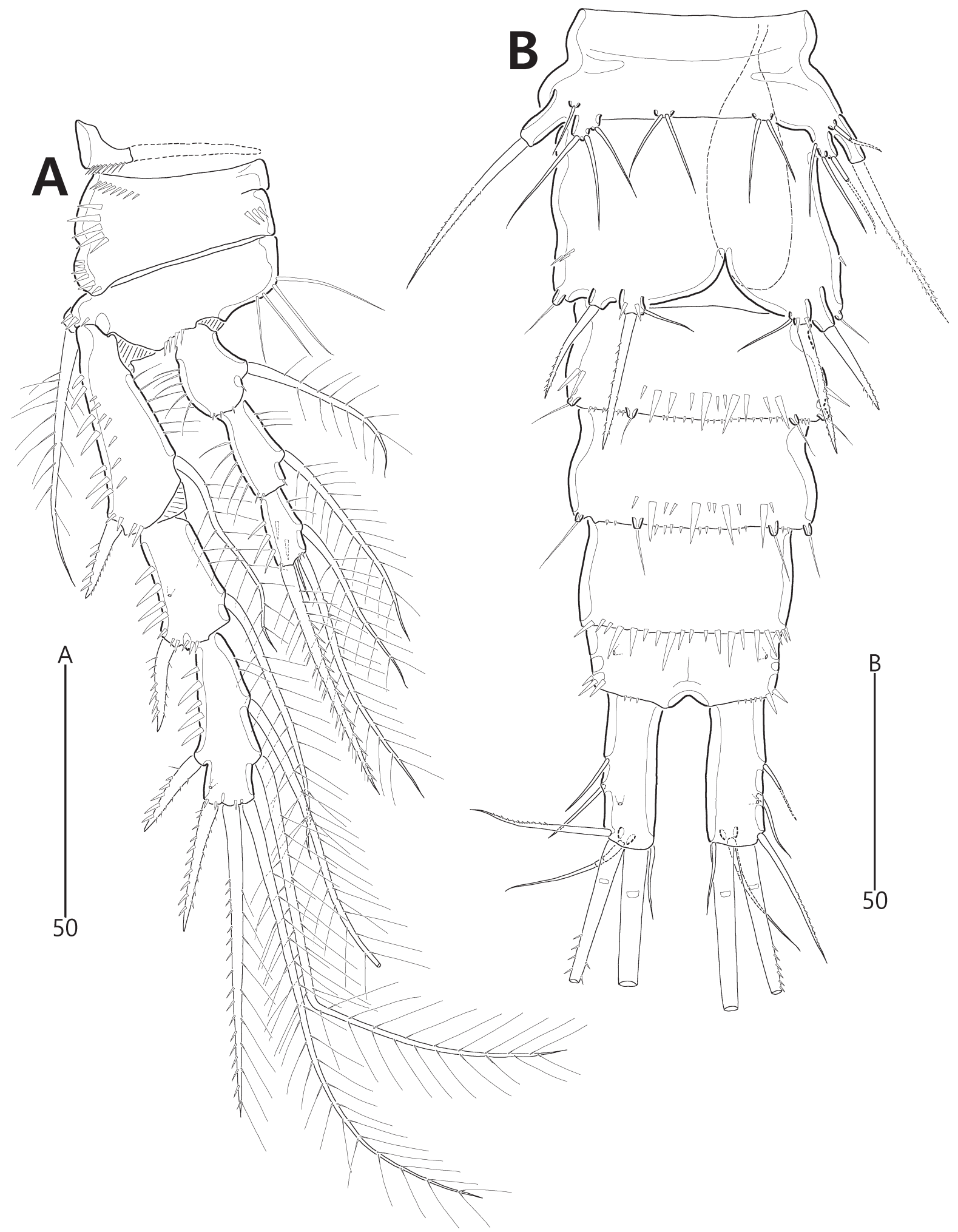

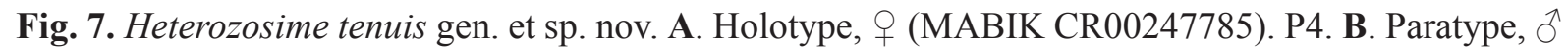
(MABIK CR00247789). Urosome, ventral view. 


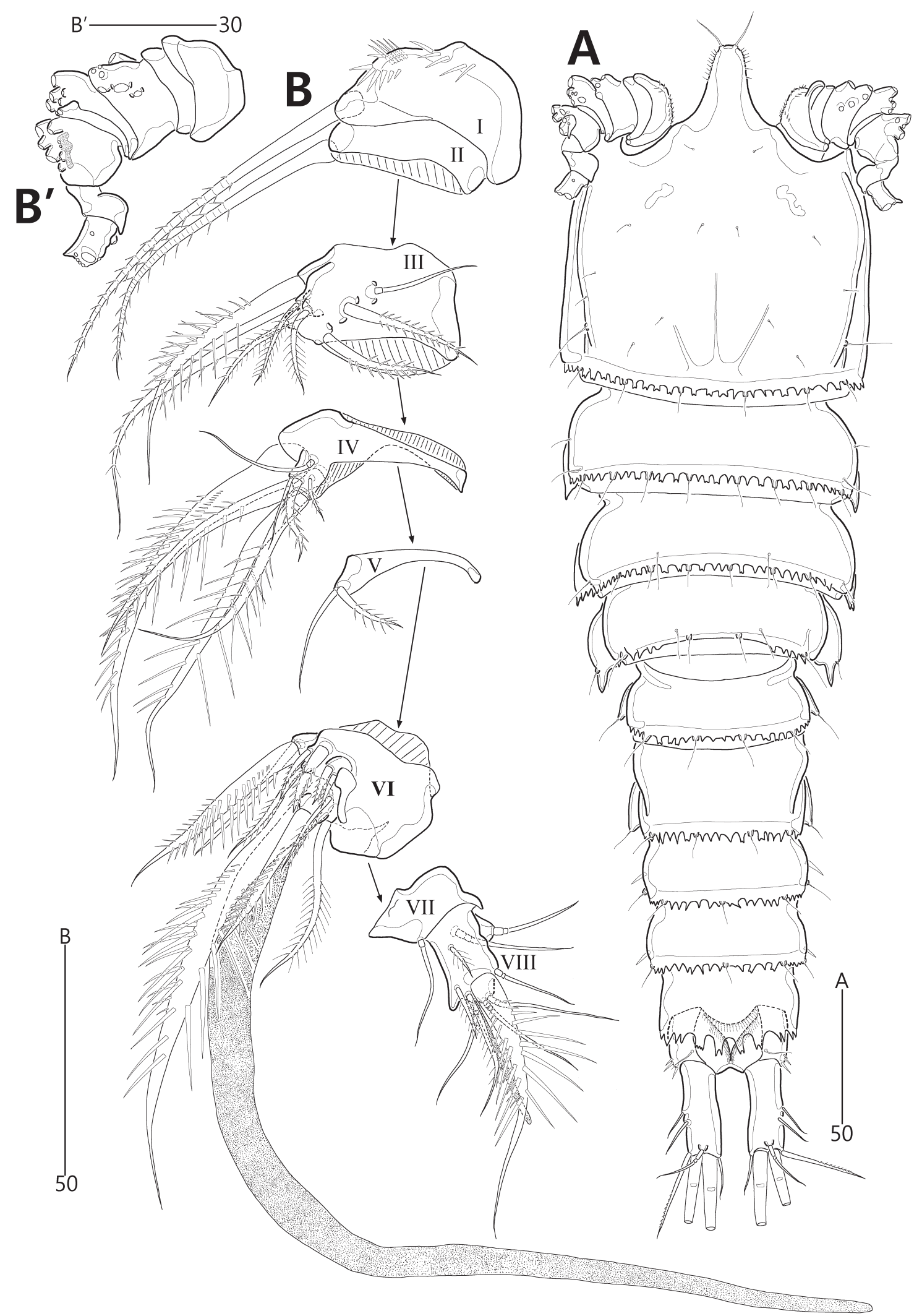

Fig. 8. Heterozosime tenuis gen. et sp. nov. Paratype, ô (MABIK CR00247789). A. Habitus, dorsal view. B. Antennule. B'. Antennule without ornamentation. 


\section{Genus Acritozosime gen. nov. urn:lsid:zoobank.org:act:E2108940-B5E2-47CC-8199-17CB29513F41}

\section{Type species}

Acritozosime spinesco gen. et sp. nov., by monotypy.

\section{Diagnosis}

Body subcylindrical, with distinct constriction between prosome and urosome. Penultimate somite with weak pseudoperculum. Rostrum undefined at base, with 1 pair of long sensilla distally. Caudal rami short, slightly longer than wide; principal seta $\mathrm{V}$ very long, about $4 / 5$ of body length. Antennule robust, 7-segmented, with ae on second and distal segment, respectively. Antennary exopod 3-segmented; setal armature, from proximal: 2.0.4; distal endopodal segment with lateral armature comprising 3 stout elements and distal armature composed of 7 elements. Mandibular palp well-developed, with 2 setae on basis; exopod 1-segmented, with 4 setae; endopod 1-segmented, with 4 distal setae and 1 lateral seta. Maxillular coxa without epipodite; exopod 1-segmented, with 2 setae; endopod 1-segmented, with 5 setae. Maxillary syncoxa with 3 endites; endopod 2-segmented. Maxilliped stenopodial, forming right angle between syncoxa and basis; syncoxa with 2 setae; basis gradually extended toward distal end, with 1 seta; endopod small, 1-segmented, with 4 setae. P1 with 2-segmented exopod and endopod; enp1 without inner seta. P2-P4 with 3-segmented exopod and 2-segmented endopod; exp-3 with 2 outer spines; P2-P3 enp-1 without inner seta. Female P5 exopod and baseoendopod separate; exopod with 3 marginal setae. P6 represented by 1 long and 2 small setae. Male unknown.

\section{Etymology}

The generic name is a combination of the Greek 'akritos' meaning 'confused' or 'mixed' and the name of the type genus Zosime. It refers to several morphological features intermediate between the families Idyanthidae and Zosimeidae.

$$
\begin{aligned}
& \text { Acritozosime spinesco gen. et sp. nov. } \\
& \text { urn:1sid:zoobank.org:act:838FDBD8-4A20-4696-B885-6486ABD1B732 } \\
& \text { Figs 9-12 }
\end{aligned}
$$

\section{Etymology}

The species epithet is derived from the Latin intransitive verb 'spinesco' ('grow spiny'), alluding to the spinulose ornamentation on the urosome.

\section{Material examined}

Holotype

NORTHWESTERN PACIFIC • + ; East Mariana Basin; 18¹7'26.64" N, 14950'14.88" E; stn WP1908; depth 5317 m; 3 Oct. 2019; J.G. Kim leg.; MABIK CR00247790 (preserved in 80\% ethanol).

\section{Paratypes}

NORTHWESTERN PACIFIC • 1 \%; same collection data as for holotype; MABIK CR00247791 (on 11 slides) 1 1 ; same collection data as for holotype; MABIK CR00247792 (preserved in $80 \%$ ethanol).

\section{Other material}

NORTHWESTERN PACIFIC • 1 \%; East Mariana Basin; 1851'56.22" N, 149 51'40.20" E; stn WP1909; depth 5416 m; 4 Oct. 2019; J.G. Kim leg.; MInRB-Hr61-L001 (preserved in 80\% ethanol) • 1 o; East Mariana Basin; 19¹9'45.78" N, 150¹9'19.26" E; stn WP1910; depth 5078 m; 5 Oct. 2019; J.G. Kim leg.; MInRB-Hr61-S001 (on four slides) • 1 +; same collection data as for preceding; MInRB-Hr61-L002 
(preserved in 80\% ethanol) - 1 copepodid; East Mariana Basin; 1901'26.4" N, 151 $08^{\prime} 49.56^{\prime \prime}$ E; stn WP1912; depth 5550 m; 17 Oct. 2019; J.G. Kim leg.; MInRB-Hr61-L003 (preserved in 80\% ethanol) - 1 O ; Philippine Basin of the Philippine Sea; 1959'37.14" N, 128 $21^{\prime} 49.13^{\prime \prime}$ E; stn WP1802; depth 5642 m; 19 Oct. 2018; J. Lee leg.; MInRB-Hr61-L004 (preserved at 80\% ethanol) • 1 \%; Philippine Basin of the Philippine Sea; 18 $51^{\prime} 30.05^{\prime \prime}$ N, 129 10'44.22" E; stn WP1803; depth 5578 m; 20 Oct. 2018; J. Lee leg.; MInRB-Hr61-L005 (preserved at 80\% ethanol) • 1 \%; Philippine Basin of the Philippine Sea; $17^{\circ} 28^{\prime} 40.73^{\prime \prime}$ N, 131 $11^{\circ} 01.68^{\prime \prime}$ E; stn WP1804; depth 5856 m; 22 Oct. 2018; J. Lee leg.; MInRBHr61-L006 (preserved at 80\% ethanol).

\section{Description}

Female (based on the paratype MABIK CR00247791)

MeAsurements. Body length about 406-535 $\mu \mathrm{m}$ (mean $479 \mu \mathrm{m}, \mathrm{n}=10$; holotype $437 \mu \mathrm{m}$ ) measured from anterior tip of rostrum to posterior end of caudal rami in lateral aspect.

Habitus (Fig. 9A-B). Semi-cylindrical, slightly depressed dorsoventrally, tapering posteriorly; with distinct constriction between prosome and urosome. Rostrum (Fig. 9A) large, broad, triangular, reaching to mid-length of third antennular segment, fused to cephalothorax basally; anterior tip with a pair of sensilla. Cephalothorax slightly longer than wide, with almost parallel lateral margins in dorsal aspect. First pedigerous somite completely incorporated into cephalothorax. Second to fourth free pedigerous somites slightly tapering posteriorly. Urosome (Figs 9A-B, 10A) composed of P5 bearing-somite, genital double-somite and 3 abdominal somites, about 0.8 times as long as prosome. Genital double-somite formed by dorsal and ventral fusion of genital and first abdominal somites; mark of original division remains internally on both lateral sides; gonopores (Fig. 10C) fused medially forming single genital slit covered by single broad plate bearing 1 stout spinulose seta and 2 small spines, representing P6, on both sides distally; copulatory pore large, located in midventral surface posterior to genital slit, connected to pair of internal seminal receptacles. Penultimate somite (Figs 9A-B, 10A-B) with pseudoperculum bearing 4 weak protuberances (two of them damaged and represented by a dotted line in Fig. 10B). Anal somite (Figs 9A-B, 10A-B) small, with small operculum bearing distal setules; dorsal surface with 1 pair of sensilla; anal opening wide, armed with 2 diagonal rows of setules.

BODY ORNAMENTATIONS. Integument of cephalothorax ornamented with paired pores and sensilla and other somites except penultimate and anal somites ornamented with paired sensilla posteriorly (Fig. 9A-B). Hyaline frills of all somites weak; genital double-somite, second and third abdominal somites irregular dorsally. Urosomites armed with posterior spinules laterally in all somites and dorsally in first urosomite and first abdominal somite.

Caudal Rami (Figs 9A-B, 10A-B). Slightly longer than anal somite, about 1.8 times as long as greatest width; inner margin convex proximally, ornamented with setules; with 7 setae: ventrolateral seta I smallest, inserted at mid-length of outer margin; dorsolateral seta II about 1.1 times as long as caudal ramus, inserted at same level as seta I; seta III arising from ventral surface subdistally, about twice as long as caudal ramus; setae II and III accompanied by few spinules at their bases; principal setae IV and V well-developed, tri-spinulose, with internal fracture plane proximally; seta IV about $1 / 3$ of seta $\mathrm{V}$ length; seta $\mathrm{V}$ very long, about $4 / 5$ of body length; seta VI inserted at inner distal corner ventrally, as long as caudal ramus; seta VII tri-articulate basally, located dorsally in mid-length of inner margin.

Antennule (Fig. 10D). Short, robust, 7-segmented. First segment ornamented with inner spinules and with 1 pinnate seta bearing a few spinules near base. Second segment largest, partially with cuticular ridge indicating original segmentation; with 7 pinnate setae, 5 spinulose setae, 5 tri-spinulose setae, of which one is bi-articulated basally, and 1 ae. Third segment small, with 1 small spinulose seta and 1 stout tri-spinulose seta. Fourth segment small, with 2 spinulose setae. Fifth segment small with 1 bare 


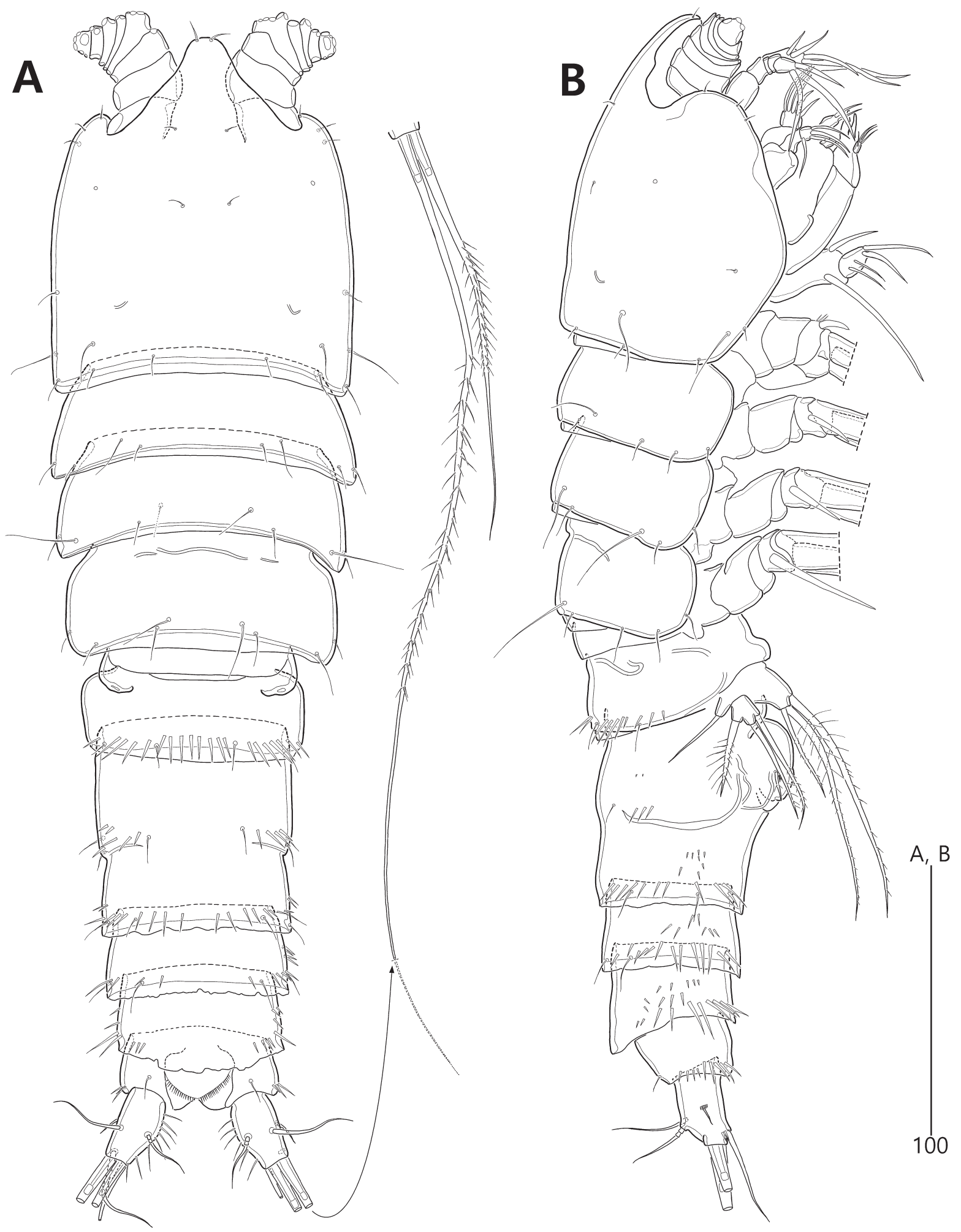

Fig. 9. Acritozosime spinesco gen. et sp. nov. Paratype, + (MABIK CR00247791). A. Habitus, dorsal view. B. Habitus, lateral view. 
bi-articulate seta, 1 spinulose seta and 1 stout tri-spinulose seta. Sixth segment smallest, with 1 spinulose seta and 1 bare bi-articulate seta. Seventh segment small, with 1 small spinulose, 1 stout tri-spinulose, 1 spinulose and 2 bare bi-articulate setae and 1 ae. Each ae on second and distal segments fused basally with adjacent spinulose seta. Setal armature formula as: 1-[1], 2-[16+ $(1+\mathrm{ae})], 3-[2], 4-[2], 5-[3], 6-[2]$, $7-[4+(1+a e)]$.

Antenna (Fig. 11A). Coxa small, unornamented. Basis small, with 2 short rows of setules and 1 small spinulose abexopodal seta. Exopod large, 3-segmented; proximal segment with 1 short bare seta proximally and 1 spinulose seta distally; middle segment smallest, unarmed; distal segment as long as two preceding segments combined, with 1 spinulose lateral and 3 spinulose distal setae. Endopod 2-segmented; proximal segment small, unarmed; distal segment about twice as long as preceding one, ornamented with 2 rows of spinules on lateral margin proximally and 1 row of spinules on distal margin; lateral armature comprising 3 stout spinulose setae; distal armature composed of 2 spinulose rigid setae, 2 uni-spinulose setae, of which longest fused to adjacent spinulose rigid seta basally, and 3 spinulose geniculate setae.

MANDiBle (Fig. 11B). Coxa with bulge medially; gnathobase armed with several multicuspidate teeth and 1 dorsal unipinnate spine. Palp comprising basis, exopod and endopod; basis elongate, with 2 plumose setae subdistally; exopod 1-segmented, with 4 spinulose setae; endopod 1-segmented, with 1 uniplumose seta laterally and 4 spinulose setae distally.

MAXILLULE (Fig. 11C). Praecoxa ornamented with 1 row of spinules near outer margin; arthrite developed, with 2 parallel setae and 2 rows of spinules on anterior surface, 1 row of spinules on posterior surface and 7 stout spines, 1 small bare seta and 1 unipinnate seta along distal margin. Coxa small, without epipodite; endite with 1 pinnate and 2 plumose setae. Basis ornamented with 2 rows of dorsal spinules, with 3 bare and 4 pinnate setae apically and subapically. Exopod smaller than endopod, with 2 plumose setae distally. Endopod transversely elongate, with 1 bare and 2 pinnate setae distally and 1 pinnate and 1 plumose seta subdistally.

Maxilla (Fig. 11D). Syncoxa ornamented with 1 row of setules on outer margin; two praecoxal endites fused basally, proximal one ornamented with rows of spinules on lateral margin and anterior surface, respectively, with 2 spinulose spines distally and distal one with 1 spinulose seta, 1 bare seta and 1 unispinulose spine; both coxal endites elongate, with 1 bare and 2 spinulose setae, respectively. Allobasis with 2 stout uniserrate spines and 1 bare seta. Endopod small, 2-segmented; proximal with 2 bare setae; distal one with 3 uniplumose setae distally and 1 bare seta subdistally.

MAXILLIPED (Fig. 11E). Comprising syncoxa, basis and endopod, forming right angle between syncoxa and basis. Syncoxa ornamented with 3 short rows of spinules; with 1 spinulose seta subdistally and 1 long tri-spinulose seta proximally, which is about 3 times as long as syncoxa. Basis with 1 spinulose seta distally; inner margin extended distally, bearing 1 row of long spinules. Endopod small, with 2 stout spinulose setae distally and 2 bare setae laterally.

P1 (Fig. 11F). Praecoxa large, unornamented. Both coxae connected by pentagonal intercoxal sclerite. Coxa wide, with 2 rows of long outer spinules and 1 row of minute distal spinules on anterior surface. Basis wide, with 1 spinulose outer spine and 1 spinulose inner spine, ornamented with 2 groups of spinules on anterior surface, 1 row of long setules along inner margin, 1 row of spinules near distal margin and 1 row of spinules near base of outer and inner spines; inner spine displaced onto anterior surface. Exopod 2-segmented, as long as endopod; exp-1 with 1 unispinulose outer spine; ornamented with 3 groups of outer spinules, 3 rows of anterior spinules and 1 row of inner setules; exp-2 slightly larger than exp-1, ornamented with 4 groups of spinules near base of spines, with 3 unispinulose outer spines, 2 spinulose distal spines, of which inner one armed with inner setules, and 1 small plumose inner 


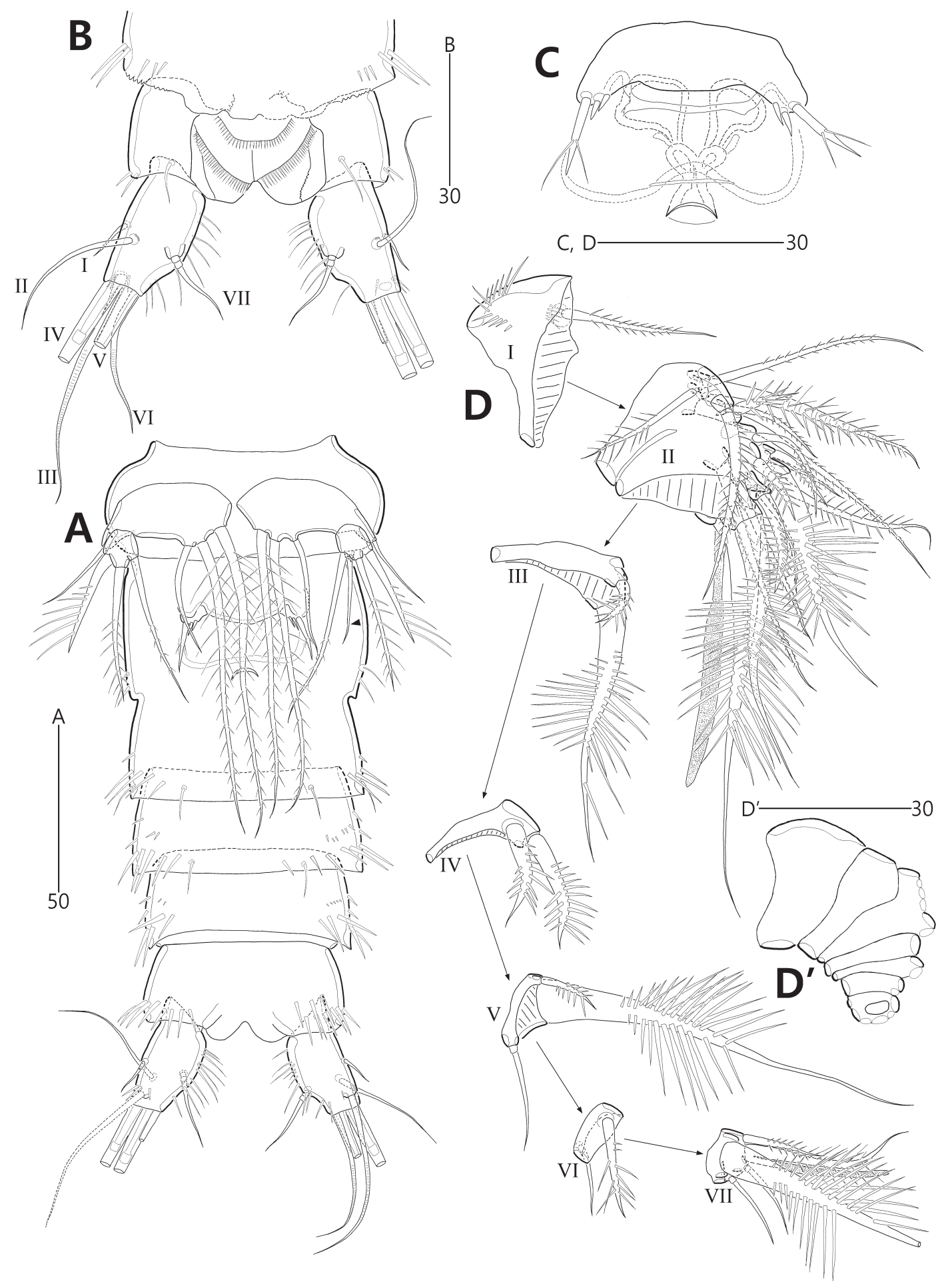

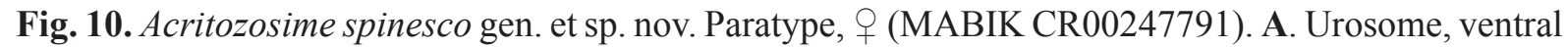
view; arrowhead indicates an abnormal condition of the P5 exopod. B. Posterior end of penultimate somite, anal somite, and caudal rami, dorsal view. C. Genital field, ventral view. D. Antennule. D'. Antennule without ornamentation. 


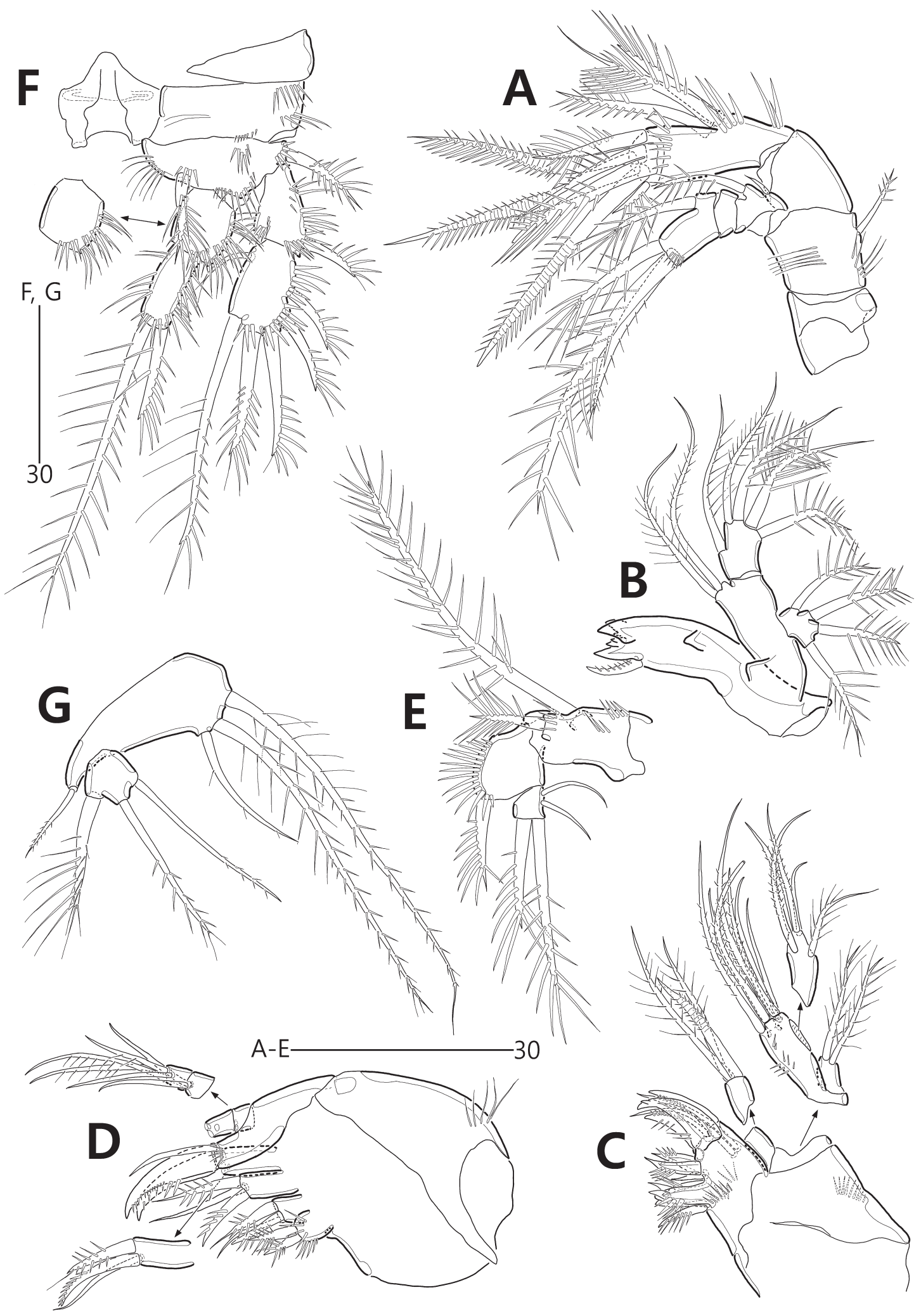

Fig. 11. Acritozosime spinesco gen. et sp. nov. Paratype, $q$ (MABIK CR00247791). A. Antenna. B. Mandible. C. Maxillule. D. Maxilla. E. Maxilliped. F. P1. G. P5. 
seta; all outer spines with gradually increasing outer spinules toward distal tip. Endopod 2-segmented; enp-1 subrectangular, unarmed, ornamented with rows of spinules along outer margin and 2 rows of anterior spinules near outer distal corner; enp-2 with 1 small spinulose spine and 1 long spinulose seta (inner seta about 3 times as long as outer spine) on distal margin, ornamented with rows of spinules along outer and inner margins and 1 row of anterior spinules near distal margin (Table 2).

P2-P4 (Fig. 12A-C). Praecoxae short but wide, with 1 row of distal spinules near outer margin. Both coxae connected by pentagonal intercoxal sclerite bearing concave posterior margin. Coxae large, wide, with 1 row of anterior spinules near outer margin. Bases wide, ornamented with 1 group of long setules along inner margin, 1 row of distal spinules on pedestal of inner ramus and 1 group of anterior spinules near base of outer setophore; outer seta arising from setophore, stout and spinulose. Exopods longer than endopods, 3-segmented; exp-1 elongate, largest, with 1 spinulose outer spine, ornamented with 3 groups of spinules along outer margin, 1 row of setules on inner margin, 1 row of minute spinules on distal margin and 1 row of anterior spinules near base of outer spine; exp-2 smallest, with 1 spinulose outer spine and 1 plumose inner seta, ornamented with 1 row of spinules on outer margin, few setules on inner margin and 1 group of anterior spinules near base of outer spine; exp-3 elongate, with 2 spinulose outer spines, 1 (outer) distal spine, which is armed with inner setules and outer spinules, 1 plumose (inner) distal seta and 1 (in P2) or 2 (in P3-P4) plumose inner setae; ornamented with 1 row of spinules on outer margin and 3 groups of spinules near base of outer spines. Endopods slightly exceeding end of exp-2 (in P2 and P4) or reaching to distal fourth of exp-2 (in P3), 2-segmented; enp-1 armed with outer and inner setules/spinules; P2 enp-1 ornamented with anterior spinules near distal margin; P2-P3 enp-1 unarmed and $\mathrm{P} 4$ enp-1 with 1 plumose inner seta; enp-2 elongate, ornamented with outer, inner and distal (absent in P2) setules/spinules; P2 enp-2 with 1 short spinulose outer spine and 1 long plumose distal seta; P3-P4 enp-2 with 2 long plumose setae on distal margin and 1 plumose seta on inner margin (Table 2).

P5 (Figs 10A, 11G). Baseoendopod wide, with outer setophore bearing 1 weakly pinnate seta; endopodal lobe weakly pronounced, reaching to mid-length of exopod; with 3 setae distally, outermost one small, weakly pinnate, of which 2 inner ones plumose proximally and spinulose distally. Exopod small, with 3 setae; outermost one armed with long spinules and 2 inner ones spinulose distally.

\section{Male \\ Unknown.}

\section{Variability}

A paratype female specimen (MABIK CR00247791) exhibits two abnormal conditions in the P4 enp-1 and P5 exopod. The right leg of the P4 lacks an inner seta on the proximal endopodal segment (Fig. 12D, arrowhead) and the left leg of the P5 has four setae on the exopod (Fig. 10A, arrowhead). These setal abnormalities were not detected in other examined specimens.

\section{Remarks}

Interestingly, this new species exhibits several characteristics intermediate between those of the families Idyanthidae and Zosimeidae. Detailed morphological examination revealed that certain characteristics of the antenna and maxilliped resemble those of idyanthid copepods. The antenna of Acritozosime spinesco gen. et sp. nov. shares the presence of two elements on the proximal exopodal segment with the idyanthid genera Idyanthe Sars, 1909, Idyella Sars, 1905, Idyellopsis Lang, 1948, Nematovorax Bröhldick, 2005 and Tachidiella Sars, 1909 (all known zosimeid copepods have only one seta); and the distal endopodal segment bears seven elements as in members of the Idyanthidae (zosimeid species have at most six setae). The maxilliped of $A$. spinesco gen. et sp. nov. resembles those of idyanthid copepods in the presence of a joint between the syncoxa and basis and the presence of two setae on the syncoxa (members of the Zosimeidae have no setae on that segment, except for Zosime eliasi Pointner, 


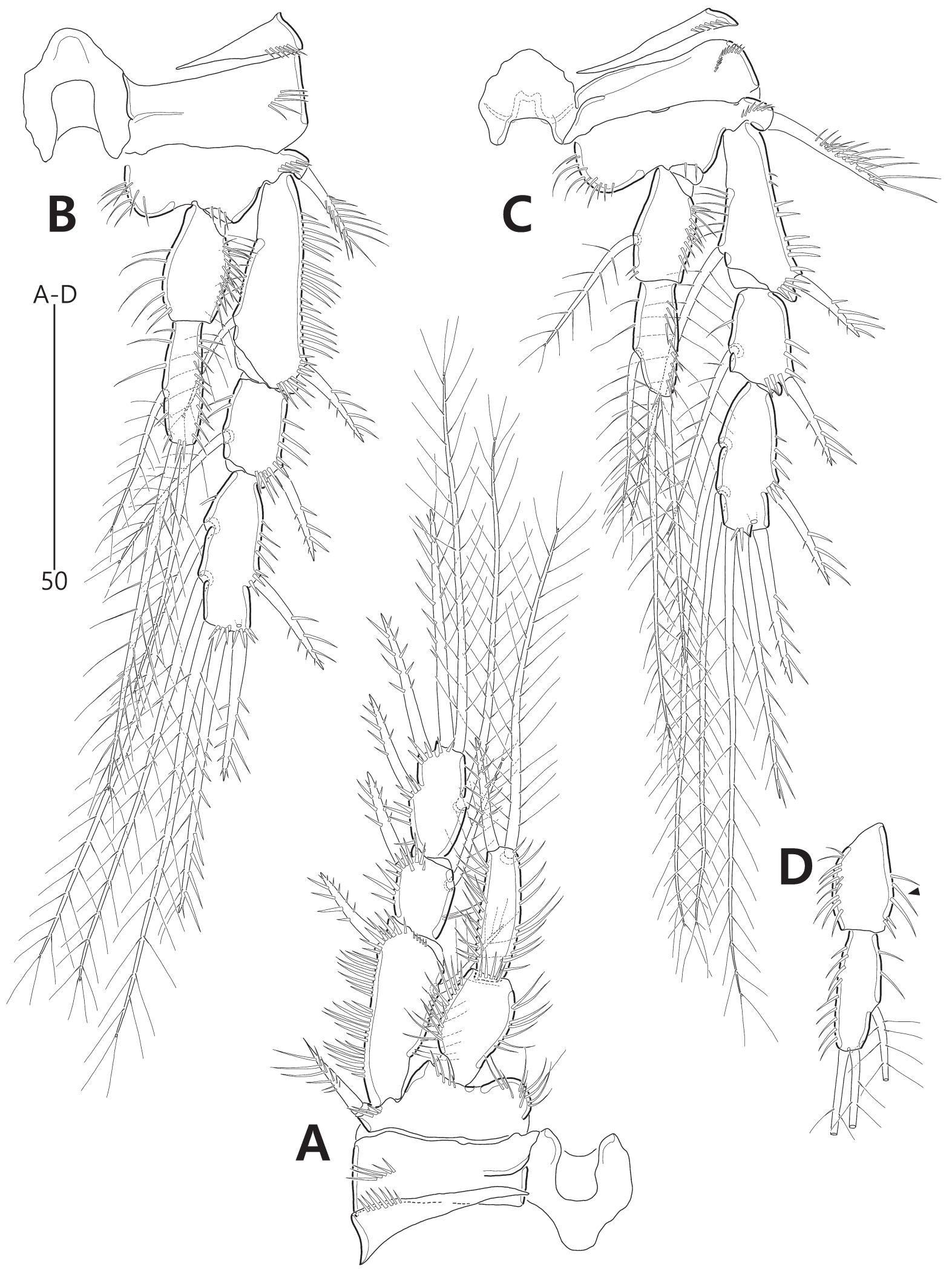

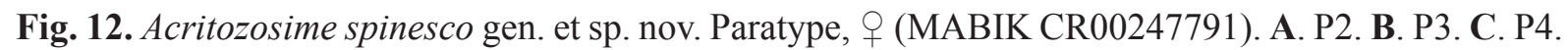
D. Abnormal condition of $\mathrm{P} 4$ endopod lacking an inner seta on the proximal segment. 
2017 having one seta). However, this new taxon also seems to have a close affinity with the family Zosimeidae as shown by the following features: (1) the female antennules are short, robust and armed with stout tri-spinulose setae; this is not the case in the Idyanthidae other than Tachidiella; (2) the distal endopodal segment of the antenna has a lateral armature composed of three elements (vs four setae in the Idyanthidae); (3) the mandibular endopod has only one lateral seta (vs 2-3 setae as in Idyanthe, Idyella and Tachidiella of the Idyanthidae); (4) the mandibular exopod is one-segmented, with four setae (vs two-segmented, with four setae on proximal segment and two setae on the distal one as in Styracothorax and Tachidiella of the Idyanthidae); (5) the maxillular exopod is smaller than the endopod (vs longer than the endopod as in Idyellopsis of the Idyanthidae); (6) all endites on the maxillary syncoxa are displaced toward the anterior half (vs the praecoxal endite is displaced toward the proximal half as in Idyella of the Idyanthidae); (7) the maxilliped has a small and almost square endopod bearing four non-geniculate elements (vs with geniculate setae or strong claws as in Idyanthe, Idyella, Meteorina and Styracothorax of the Idyanthidae); (8) the P1 enp-1 is almost square (vs elongate and broadened at the level of the inner element in the Idyanthidae); and (9) the shape of the female P5 is similar to that of Zosime bathybia Bodin, 1968, although the number of setae on the exopod differs.

Seifried (2003) listed four significant autapomorphies of the Idyanthidae: (1) the mandibular exopod has a long proximal segment bearing four setae and a small distal segment bearing two setae; (2) the maxillulary exopod is elongate; (3) the P1 enp-1 is elongated and broadened at the level of the inner seta; and (4) the proximal outer seta on the female P5 exopod is inserted near the basis. Acritozosime spinesco gen. et sp. nov. does not share these characteristics. Instead, this new species exhibits several autapomorphies of the Zosimeidae in the antennary endopod, mandibular both rami, maxillulary exopod, maxillary syncoxa, maxillipedal endopod and P1 endopod as mentioned above (characters $2-8$ in the previous paragraph). Therefore, we suggest that an allocation of $A$. spinesco gen. et sp. nov. to the Zosimeidae is more reasonable; the organism retains certain plesiomorphic conditions (at least in the antenna and maxilliped) of Idyanthidimorpha, as noted above. Within the Idyanthidimorpha, the sexual dimorphism of the male P2 is a clue to the taxonomic position of the harpacticoids (Moura \& Martínez Arbizu 2004; Bröhldick 2005). Unfortunately, we could not confirm this character state because we lacked males of the new species.

Within the Zosimeidae, the most conspicuous characters of $A$. spinesco gen. et sp. nov. are the reduced segmentation and setal armature of the thoracic legs. The new species shares the two-segmented endopod in the thoracic legs with Pseudozosime, but differs from it by the reduced setal armature; the inner element of the proximal endopodal segment is lost in P1-P3; the distal exopodal segment in P2-P4 has two outer spines instead of three. All zosimeid copepods have one or two inner setae on the distal endopodal segment of $\mathrm{P} 1$, while these are lacking in $A$. spinesco gen. et sp. nov.

This new species is also characterized by the following unambiguous features: (1) the loss of abexopodal elements on the proximal endopodal segment of the antenna (present in other zosimeid genera); (2) the lack of an epipodal element on the coxa of the maxillule (present in other zosimeid genera); and (3) the caudal seta $\mathrm{V}$ is notably elongated, being at least $80 \%$ of the total body length.

\section{Discussion}

Within the family Zosimeidae, the two new genera, Heterozosime gen. nov. and Acritozosime gen. nov., share a robust characteristic of the P1 exopod. In both genera, this ramus consists of only two segments, which is unique to the family and can be regarded as autapomorphies for both genera, supporting the establishment of two genera for $H$. tenuis gen. et sp. nov. and $A$. spinesco gen. et sp. nov., respectively. Despite sharing this derived state, it seems that the ramus differs fundamentally between $H$. tenuis gen. et sp. nov. and A. spinesco gen. et sp. nov. Fiers (1991) discussed the development of copepodids in Zosime pacifica Fiers, 1991; this species has a three-segmented P1 exopod as do other zosimeid 
copepods. During ontogeny, the middle and distal segments of the P1 exopod separated during the transition from copepodid IV stage to V (see Fiers 1991: table II); consequently, the ramus setations were rearranged from 0.223 to 0.1 .123 . In the case of $H$. tenuis gen. et sp. nov., the adult female armature is similar to that of copepodid IV of Z. pacifica, with two inner setae the distal segment. A comparison of the setal positions on the ramus reveals that the two inner setae on the distal segment are homologous to those of Z. pacifica, indicating that the two-segmented P1 exopod of H. tenuis gen. et nov. is probably derived by suppression of middle/distal exopodal segment separation in copepodid IV. In contrast, the distal segment of this ramus in the adult female of $A$. spinesco gen. et sp. nov. has only one (not two) inner seta(e) proximally. The absence of a distal inner element suggests that either the original third segment of $A$. spinesco gen. et sp. nov. had no inner elements or that a seta has been secondarily lost during ontogeny. This seta is present in all other zosimeid copepods. Thus, it seems that A. spinesco gen. et sp. nov. has undergone an evolutionary history that differs from those of other genera. This suggestion is supported by the several unambiguous autapomorphies (the absence of an epipodal element on the maxillular coxa and the absence of inner setae on the P2-P3 enp-1), and retention of certain plesiomorphic states (the antennary exopod features two setae on the proximal segment and the maxillipedal syncoxa contains two elements (see our remarks above on $A$. spinesco gen. et sp. nov.)). As plesiomorphic features of the Idyanthidimorpha are evident in the antenna and maxilliped, this deep-sea species seems to occupy a ground position within the Zosimeidae.

Bröhldick (2005) established the genus Nematovorax for N. gebkelinae Bröhldick, 2005 from the deep Angola Basin in the South Atlantic and placed it in the family Idyanthidae. She recognized that the new taxon exhibited several characteristics of both the Idyanthidae and Zosimeidae, rendering it difficult to derive its exact taxonomic position within the Idyanthidimorpha. For example, the P1 endopod is twosegmented as in members of the Zosimeidae, but the sexual dimorphism of the P2 endopod is identical to that of idyanthid copepods lacking the inner elements of the male P2 enp-3 (Bröhldick 2005). Given that three important apomorphies (in the P1 enp-1, P5 exopod and male P2 enp-3) are shared with the Idyanthidae, Bröhldick (2005) allocated Nematovorax to that taxon. Bröhldick (2005) also examined many undescribed species (e.g., Nematovorax sp. 1 and Nematovorax sp. 2) from DIVA 1 samples (obtained in the study area yielding the new Nematovorax species); these retained many plesiomorphic conditions (as did N. gebkelinae), suggesting that they might be a sister-group of the IdyantidaeZosimeidae. However, Bröhldick (2005) hesitated to erect a new family for N. gebkelinae given the absence of certain familial autapomorphies of these taxa. The morphology of female A. spinesco gen. et sp. nov. from the northwestern Pacific resembles that of $N$. gebkelinae as follows: (1) the female antennule is short and robust; (2) the proximal exopodal segment of the antenna features two lateral setae; (3) the distal armature of the distal endopodal segment of the antenna consists of seven elements; (4) the armature of the mandibular endopod features one lateral and four distal setae; (5) the maxilliped is jointed between the syncoxa and basis and the syncoxa has two elements; and (6) the single genital slit has one long seta and two minute setae on both sides. We suggest that these morphological similarities may imply that Bröhldick's assumption is correct; alternatively, convergence may be in play. Nevertheless, using the current taxonomic criteria, we place $A$. spinesco gen. et sp. nov. in the Zosimeidae based on the absence of the four apomorphies of the Idyanthidae, pending the discovery of many undescribed species related to Nematovorax or Acritozosime gen. nov. Indeed, many records of unidentified species that may be related to the former species have been reported from the deep sea: $N$. cf. gebkelinae from the northeastern Pacific off the western coast of the United States (Easton \& Thistle 2016); a Nematovorax species from the Ryukyu Trench around Japan (Kitahashi et al. 2014); six unrecorded genera of the Idyanthidae from the eastern Mediterranean Anaximenes Seamount (George et al. 2018); Nematovorax sp. nov. from the Voronin Trench of the Kara Sea (Garlitska et al. 2019); and two new species of Idyanthidae from the Porcupine Seabight in the northeastern Atlantic (Gheerardyn et al. 2009). These species will allow us to accumulate the morphological knowledge required to reevaluate the phylogenetic relationships among genera of the Idyanthidimorpha. 


\section{Acknowledgements}

We would like to thank the captains and crews of the RV EARDO, ONNURI and ISABU for collecting samples and the scientific members on board for support during the oceanographic cruises. This research was supported by the National Marine Biodiversity Institute Research Program (2021M01100) of Korea. The oceanographic cruise that resulted in the discovery of a deep-sea species was financed by a research programme (Contract No. PE99924) of the Korea Institute of Ocean Science and Technology (KIOST). The first author acknowledges a research grant from the National Research Foundation of Korea (NRF) through the Korea government (MSIT) (No. 2021R1F1A1049063).

\section{References}

Bröhldick K.S.T. 2005. A new taxon of Idyanthidae (Copepoda, Harpacticoida) from the deep sea of the Angola Basin. Organisms Diversity \& Evolution 5 (suppl. 1): 43-57.

https://doi.org/10.1016/j.ode.2004.10.004

Burgess R. 2001. An improved protocol for separating meiofauna from sediments using colloidal silica sols. Marine Ecology Progress Series 214: 161-165. https://doi.org/10.3354/meps214161

Easton E.E. \& Thistle D. 2016. Do some deep-sea, sediment-dwelling species of harpacticoid copepods have 1000-km-scale range sizes? Molecular Ecology 25 (17): 4301-4318.

https://doi.org/10.1111/mec.13744

Fiers F. 1991. Three new harpacticoid copepods from the Santa Maria Basin off the Californian Pacific coast (Copepoda, Harpacticoida). Beaufortia 42 (2): 13-47. Available from

https://repository.naturalis.n1/pub/504780 [accessed 18 Jun. 2021].

Garlitska L.A., Chertoprud E.S., Portnova D.A. \& Azovsky A.I. 2019. Benthic Harpacticoida of the Cara sea: species composition and bathymetric distribution. Okeanologiya 59 (4): 600-611. [In Russian]. https://doi.org/10.31857/s0030-1574594600-611

George K.H. 2004. Meteorina magnifica gen. et sp. nov., a new Idyanthidae (Copepoda, Harpacticoida) from the plateau of the Great Meteor Seamount (Eastern North Atlantic). Meiofauna Marina 13: 95-112.

George K.H., Veit-Köhler G., Martínez Arbizu P., Seifried S., Rose A., Willen E., Bröhldick K., Corgosinho P.H., Drewes J., Menzel L., Moura G. \& Schminke H.K. 2014. Community structure and species diversity of Harpacticoida (Crustacea: Copepoda) at two sites in the deep sea of the Angola Basin (Southeast Atlantic). Organisms Diversity \& Evolution 14: 57-73.

https://doi.org/10.1007/s13127-013-0154-2

George K.H., Pointner K. \& Packmor J. 2018. The benthic Copepoda (Crustacea) of Anaximenes Seamount (eastern Mediterranean Sea) - Community structure and species distribution. Progress in Oceanography 165: 299-316. https://doi.org/10.1016/j.pocean.2018.06.006

Gheerardyn H., de Troch M., Vincx M. \& Vanreusel A. 2009. Harpacticoida (Crustacea: Copepoda) associated with cold-water coral substrates in the Porcupine Seabight (NEAtlantic): species composition, diversity and reflections on the origin of the fauna. Scientia Marina 73 (4): 747-760.

https://doi.org/10.3989/scimar.2009.73n4747

Huys R. 1993. Styracothoracidae (Copepoda: Harpacticoida), a new family from the Philippine deep sea. Journal of Crustacean Biology 13 (4): 769-783. https://doi.org/10.1163/193724093X00336

Huys R. \& Boxshall G.A. 1991. Copepod Evolution. The Ray Society, London.

Huys R., Gee J.M., Moore C.G. \& Hamond R. 1996. Marine and Brackish Water Harpacticoid Copepods. Part 1. Synopses of the British Fauna (New Series) 51, Field Studies Council, Shrewsbury, UK. 
Kim J.G. \& Lee J. 2019. New records of benthic harpacticoids from Korea: I. Three new species of the genus Zosime Boeck (Copepoda: Harpacticoida: Zosimeidae). Marine Biology Research 15 (2): 210-239. https://doi.org/10.1080/17451000.2019.1619774

Kim J.G., Jung T.W. \& Yoon S.M. 2016. A new species of Zosime (Copepoda: Harpacticoida: Zosimeidae) from shallow subtidal habitats in Korea, with notes on the genus. Zootaxa 4136 (2): 323334. https://doi.org/10.11646/zootaxa.4136.2.4

Kitahashi T., Kawamura K., Kojima S. \& Shimanaga M. 2013. Assemblages gradually change from bathyal to hadal depth: a case study on harpacticoid copepods around the Kuril Trench (north-west Pacific Ocean). Deep-Sea Research Part I: Oceanographic Research Papers 74: 39-47. https://doi.org/10.1016/j.dsr.2012.12.010

Kitahashi T., Kawamura K., Kojima S. \& Shimanaga M. 2014. Bathymetric patterns of $\alpha$ and $\beta$ diversity of harpacticoid copepods at the genus level around the Ryukyu Trench, and turnover diversity between trenches around Japan. Progress in Oceanography 123: 54-63.

https://doi.org/10.1016/j.pocean.2014.02.007

Koller S. \& George K.H. 2011. Description of a new species of Zosime Boeck, 1872 (Copepoda: Harpacticoida: Zosimeidae) from the Great Meteor Seamount, representing one of the few eurybathic Harpacticoida among the distinct plateau and deep-sea assemblages. Meiofauna Marina 19: 109-126.

Moura G. \& Martínez Arbizu P. 2003. The phylogenetic position of the bathyal harpacticoids Aspinothorax gen. n. and Styracothorax Huys (Crustacea: Copepoda). Bulletin de l'Institut royal des Sciences naturelles de Belgique Biologie 73: 167-181.

Pointner K. 2017. Description of two new species of Zosime (Copepoda: Harpacticoida: Zosimeidae), including remarks on its phylogeny and distribution on the Great Meteor Seamount plateau (North-east Atlantic Ocean). Journal of Natural History 51 (37-38): 2283-2330.

https://doi.org/10.1080/00222933.2017.1355493

Schmidt C., Lins L. \& Brandt A. 2018. Harpacticoida (Crustacea, Copepoda) across a longitudinal transect of the Vema Fracture Zone and along a depth gradient in the Puerto Rico trench. Deep-Sea Research Part II: Topical Studies in Oceanography 148: 236-250.

https://doi.org/10.1016/j.dsr2.2017.12.024

Schmidt C., Sattarova V.V., Katrynski L. \& Martínez Arbizu P. 2019. New insights from the deep: meiofauna in the Kuril-Kamchatka Trench and adjacent abyssal plain. Progress in Oceanography 173: 192-207. https://doi.org/10.1016/j.pocean.2019.02.010

Seifried S. 2003. Phylogeny of Harpacticoida (Copepoda): Revision of "Maxillipedasphalea" and Exanechentera. Cuvillier Verlag, Göttingen, Germany.

Seifried S. 2004. The importance of a phylogenetic system for the study of deep-sea harpacticoid diversity. Zoological Studies 43 (2): 435-445.

Shimanaga M., Kitazato H. \& Shirayama Y. 2004. Temporal patterns in diversity and species composition of deep-sea benthic copepods in bathyal Sagami Bay, central Japan. Marine Biology 144: 1097-1110. https://doi.org/10.1007/s00227-003-1273-7

Shirayama Y., Kaku T. \& Higgins R.P. 1993. Double-sided microscopic observation of meiofauna using an HS-slide. Benthos Research 44: 41-44. https://doi.org/10.5179/benthos1990.1993.44_41

Manuscript received: 11 November 2020

Manuscript accepted: 1 May 2021 
Published on: 19 July 2021

Topic editor: Rudy Jocqué

Desk editor: Pepe Fernández

Printed versions of all papers are also deposited in the libraries of the institutes that are members of the EJT consortium: Muséum national d'histoire naturelle, Paris, France; Meise Botanic Garden, Belgium; Royal Museum for Central Africa, Tervuren, Belgium; Royal Belgian Institute of Natural Sciences, Brussels, Belgium; Natural History Museum of Denmark, Copenhagen, Denmark; Naturalis Biodiversity Center, Leiden, the Netherlands; Museo Nacional de Ciencias Naturales-CSIC, Madrid, Spain; Real Jardín Botánico de Madrid CSIC, Spain; Zoological Research Museum Alexander Koenig, Bonn, Germany; National Museum, Prague, Czech Republic. 